\title{
Summertime observations of elevated levels of ultrafine particles in the high Arctic marine boundary layer
}

\author{
Julia Burkart ${ }^{1}$, Megan D. Willis ${ }^{1}$, Heiko Bozem ${ }^{2}$, Jennie L. Thomas ${ }^{3}$, Kathy Law ${ }^{3}$, Peter Hoor ${ }^{2}$, Amir A. Aliabadi ${ }^{4}$, \\ Franziska Köllner ${ }^{5}$, Johannes Schneider ${ }^{5}$, Andreas Herber ${ }^{6}$, Jonathan P. D. Abbatt ${ }^{1}$, and W. Richard Leaitch \\ ${ }^{1}$ Department of Chemistry, University of Toronto, Toronto, Canada \\ ${ }^{2}$ Institute of Atmospheric Physics, Johannes Gutenberg-University, Mainz, Germany \\ ${ }^{3}$ LATMOS/IPSL, UPMC Univ. Paris 06 Sorbonne Universités, UVSQ, CNRS, Paris, France \\ ${ }^{4}$ Environmental Engineering Program, University of Guelph, Guelph, Canada \\ ${ }^{5}$ Particle Chemistry Department, Max Planck Institute for Chemistry, Mainz, Germany \\ ${ }^{6}$ Alfred Wegener Institute, Helmholtz Center for Polar and Marine Research, Bremerhaven, Germany \\ ${ }^{7}$ Environment and Climate Change Canada, Toronto, Ontario, Canada \\ Correspondence to: Julia Burkart (jburkart@chem.utoronto.ca)
}

Received: 4 August 2016 - Discussion started: 8 August 2016

Revised: 27 February 2017 - Accepted: 28 February 2017 - Published: 2 May 2017

\begin{abstract}
Motivated by increasing levels of open ocean in the Arctic summer and the lack of prior altitude-resolved studies, extensive aerosol measurements were made during 11 flights of the NETCARE July 2014 airborne campaign from Resolute Bay, Nunavut. Flights included vertical profiles (60 to $3000 \mathrm{~m}$ above ground level) over open ocean, fast ice, and boundary layer clouds and fogs. A general conclusion, from observations of particle numbers between 5 and $20 \mathrm{~nm}$ in diameter $\left(N_{5-20}\right)$, is that ultrafine particle formation occurs readily in the Canadian high Arctic marine boundary layer, especially just above ocean and clouds, reaching values of a few thousand particles $\mathrm{cm}^{-3}$. By contrast, ultrafine particle concentrations are much lower in the free troposphere. Elevated levels of larger particles (for example, from 20 to $40 \mathrm{~nm}$ in size, $\left.N_{20-40}\right)$ are sometimes associated with high $N_{5-20}$, especially over low clouds, suggestive of aerosol growth. The number densities of particles greater than $40 \mathrm{~nm}$ in diameter $\left(N_{>40}\right)$ are relatively depleted at the lowest altitudes, indicative of depositional processes that will lower the condensation sink and promote new particle formation. The number of cloud condensation nuclei $(\mathrm{CCN}$; measured at $0.6 \%$ supersaturation) are positively correlated with the numbers of small particles (down to roughly $30 \mathrm{~nm}$ ), indicating that some fraction of these newly formed particles are capable of being involved in cloud activation. Given that the summertime marine Arctic is a biologically active region, it
\end{abstract}

is important to better establish the links between emissions from the ocean and the formation and growth of ultrafine particles within this rapidly changing environment.

\section{Introduction}

Surface temperatures within the Arctic are rising almost twice as fast as in any other region of the world. As a manifestation of this rapid change the summer sea ice extent has been retreating dramatically over the past decades with the possibility that the Arctic might be ice free by the end of this century (Boé et al., 2009) or even earlier (Wang and Overland, 2012). Arctic aerosol is well known to show a distinct seasonal variation with maximum mass concentrations and a strong long-range anthropogenic influence in winter and early spring. The phenomenon, known as Arctic Haze, was identified many years ago (e.g. Barrie, 1986; Heintzenberg, 1980; Rahn et al., 1977; Shaw, 1995), and has commanded renewed attention in recent years (e.g. Law et al., 2014; Quinn et al., 2007). During summer the Arctic is more isolated from remote anthropogenic sources and represents a comparatively pristine environment. The reason is that the Arctic front (e.g. Barrie, 1986), which provides a meteorological barrier for lower-level air mass exchange, moves north of many source regions during the summer months. 
Anthropogenic and biomass burning aerosols are transported to the Arctic during the summer, but increased aerosol scavenging helps maintain the pristine conditions near the surface (e.g. Browse et al., 2012; Croft et al., 2016a; Garrett et al., 2011).

Zhang et al. (2010) discussed the impacts of declining sea ice on the marine planktonic ecosystem, which includes increasing emissions of dimethyl sulfide (DMS) that may contribute to particle formation in the atmosphere (e.g. Charlson et al., 1987; Pirjola et al., 2000). Enhanced secondary organic aerosol from emissions of biogenic volatile organic compounds is also a possibility (Fu et al., 2009). Primary emissions of aerosol particles from the ocean, such as sea salt and marine primary organic aerosol, may also increase (Browse et al., 2014). Open water tends to increase cloudiness, which means that aerosol influences on clouds are likely to be more important. Over the Arctic the effects of aerosols on clouds are especially uncertain. Models have predicted that increasing numbers of particles may lead to overall warming (Garrett, 2004) when the atmosphere exists in a particularly low particle number state now referred to being "cloud condensation nuclei (CCN) limited" (Mauritsen et al., 2011), to an overall cooling effect when increasing numbers of particles are added to an atmosphere with more particles already present (Lohmann and Feichter, 2005; Twomey, 1974). It is important to characterise particle size distributions in this pristine environment to provide a baseline against which future measurements can be compared in a warming world. Indeed, Carslaw et al. (2013) highlighted the need to understand pre-industrial-like environments with only natural aerosols in order to reduce the uncertainty in estimations of the anthropogenic aerosol radiative forcing.

Primary sources, gas-to-particle formation processes, cloud processing, atmospheric ageing, mixing and deposition are all reflected in the size distribution. Therefore, measurements of aerosol size distributions are important for understanding the processes particles undergo in addition to their potential effects on clouds. The presence of ultrafine particles (UFPs) indicates recent production as their lifetime is of the order of hours. We focus this paper on ultrafine particles as these are an indication for in situ aerosol production processes in the Arctic. We also consider the growth of newly formed particles, as that determines how important they are for climate.

Aerosol size distributions including ultrafine particles $(\mathrm{dp}<20 \mathrm{~nm})$ have been measured before at different locations throughout the Arctic. Long-term studies at ground stations such as Alert, Nunavut (Leaitch et al., 2013), Ny Alesund and Zeppelin (Engvall et al., 2008a; Ström et al., 2003, 2009; Tunved et al., 2013), both on Svalbard and very recently in Tiksi, Russia (Asmi et al., 2016), and Station Nord, Greenland (Nguyen et al., 2016), indicate a strong seasonal dependence of the size distribution with the accumulationmode aerosol dominating during the winter months and a shift to smaller particles during the summer months. New particle formation events are frequently observed from June to August. Ström et al. (2003) showed that the size distribution undergoes a rapid change from an accumulation mode dominated distribution during the winter months to an Aitken mode dominated distribution at the beginning of summer. Total number concentrations increase at the beginning of summer and roughly follow the incoming solar radiation on a seasonal scale suggesting that photochemistry is an important factor for new particle formation in the Arctic. At Ny Alesund maximum number concentrations occur in late summer and are explained by the Siberian tundra being a potential source of aerosol precursor gases (Ström et al., 2003) and marine biogenic sulfur (Heintzenberg and Leck, 1994). Analysis of air mass patterns for this region show that the shift in the size distributions is also accompanied by a change of source areas, with a dominance of Eurasian source areas in winter and North Atlantic air during summer (Tunved et al., 2013).

Particle measurements including aerosol size distributions were also conducted from ice breaker cruises such as from the Swedish ice breaker Oden (Bigg and Leck, 2001; Covert et al., 1996; Heintzenberg and Leck, 2012; Leck and Bigg, 2005; Tjernström et al., 2014) and the Canadian Coast Guard Ship ice breaker Amundsen (e.g. Chang et al., 2011). Chang et al. (2011) used model calculations to show that the appearance of ultrafine particles can be explained by nucleation and growth attributed to the presence of high atmospheric and oceanic DMS concentrations measured at the same time. The Oden expeditions focus on the pack-ice-covered high Arctic, mainly north of $80^{\circ} \mathrm{N}$ and also confirm the frequent presence of an UFP mode (e.g. Covert et al., 1996). The observations from the Oden cruises offer evidence that UFP in the inner Arctic might originate from primary sources (e.g. Heintzenberg et al., 2015; Karl et al., 2013). This is motivated by three main observations. First, a lack of sulfuric acid components in collected 15-50 nm particles (Leck and Bigg, 1999). Second, Leck and Bigg (2010) highlighted that nucleation events in the high Arctic do not follow the classical banana shaped growth curve (Kulmala et al., 2001) but enhanced levels of ultrafine particles rather appear simultaneously in distinct size ranges (Karl et al., 2012). Third, such events could not be modelled with the selected empirical nucleation mechanism for the extremely low DMS concentrations in this region (Karl et al., 2013). As a primary source, it is suggested that marine microgels might become airborne via the evaporation of fog and cloud droplets (Heintzenberg et al., 2006; Karl et al., 2013).

So far most studies that include size distribution measurements in the summertime Arctic were conducted from ground stations or ship cruises. To date there are only two studies that assess the altitude dependence of the size distribution, i.e. one in the area of Svalbard (Engvall et al., 2008b) and one from the Oden performing vertical profiles with a helicopter (Kupiszewski et al., 2013). Although no size distribution measurements were performed, Heintzen- 
berg et al. (1991) measured vertical profiles of the total particle number concentration greater than $10 \mathrm{~nm}$ during June and July 1984 over the Fram Strait-Spitsbergen area, and found a "rather uniform distribution" with altitude. Their measurements, however, were confined to $500 \mathrm{~m}$ a.s.l. and above.

In this study we present data from aerosol size distribution measurements taken from an aircraft during a 3 week period in July 2014 in the high Arctic area of Resolute Bay, Nunavut, Canada. The flights focused on vertical profiles from as low as $60 \mathrm{~m}$ above the ground up to $3 \mathrm{~km}$, as well as on low-level flights above different terrain such as fast ice, open ocean, polynyas and clouds. We focus especially on UFP (5-20 nm in diameter) and address the following questions: what are the concentrations of UFPs in the Arctic summertime, and what is their vertical distribution? What are the environmental conditions that favour occurrence of UFPs and is there evidence for growth of UFP to CCN sizes? Aside from the studies conducted near Svalbard, we believe this is the first aircraft study in the high Arctic to systematically address these specific questions. This work provides a comprehensive picture of UFPs observed during the campaign whereas a prior publication from Willis et al. (2016) detailed one UFP formation and growth event observed over Lancaster Sound.

\section{Experimental}

\subsection{Sampling platform Polar 6}

The research aircraft Polar 6 owned by the Alfred Wegener Institute, Helmholtz Center for Polar and Marine Research, Bremerhaven, Germany, served as the sampling platform. The Polar 6 is a converted DC-3 airplane (Basler BT-67) modified to work under extreme cold weather conditions. An advantage of the plane is that flights at very relatively low speeds and altitudes ( $<60 \mathrm{~m}$ a.g.l.) are possible. The cabin of the aircraft is non-pressurised. We maintained a constant survey speed of approximately 120 knots $\left(222 \mathrm{~km} \mathrm{~h}^{-1}\right)$ for measurement flights at constant altitude, and ascent and descent rates of $150 \mathrm{~m} \mathrm{~min}^{-1}$ for vertical profiles. Instruments and measurements specific to this paper are described below.

\section{Inlets}

Aerosol was sampled through a stainless steel inlet mounted to the top of the plane and ahead of the engines to exclude contamination. The tip of the inlet consisted of a shrouded diffuser that provided nearly isokinetic flow. Inside the cabin the intake tubing was connected to a stainless steel tube (outer diameter of $2.5 \mathrm{~cm}$, inner diameter of $2.3 \mathrm{~cm}$ ) that carried the aerosol to the back of the aircraft where it was allowed to freely exhaust into the cabin so that the system was not over-pressured. The stainless steel tube functioned as a manifold, off which angled inserts were used to connect sample lines to the various instruments described below. In-flight air was pushed through the line with a flow rate of approximately $55 \mathrm{~L} \mathrm{~min}^{-1}$ determined by the sum of the flows drawn by the instruments $\left(35 \mathrm{~L} \mathrm{~min}^{-1}\right)$, plus the flow measured at the exhaust of the sampling manifold $\left(20 \mathrm{~L} \mathrm{~min}^{-1}\right)$. A flow of $55 \mathrm{~L} \mathrm{~min}^{-1}$ was estimated to meet nearly isokinetic sampling criteria at survey speed and the transmission of particles through the main inlet was approximately unity for diameters between $20 \mathrm{~nm}$ to $1 \mu \mathrm{m}$ (Leaitch et al., 2016). Although the transfer of the aerosol from outside to the instruments is relatively fast ( $5 \mathrm{~s}$ or less), volatilisation of some components of the particles may have occurred. However, the growth of newly formed particles by organic condensation occurs primarily by low volatility organic components (e.g. Pierce et al., 2012). Thus, the integrity of the smaller particles is likely to have been maintained. We do expect increasing line losses of particles with sizes decreasing from $10 \mathrm{~nm}$. Therefore, our observations will underestimate $N_{5-20}$.

Trace gases ( $\mathrm{CO}$ and $\mathrm{H}_{2} \mathrm{O}$ ) were sampled through a separate inlet made of a $0.4 \mathrm{~cm}$ (outer diameter) Teflon tube entering the aircraft at the main inlet and exiting through a rear-facing $0.95 \mathrm{~cm}$ exhaust line that provided a lower line pressure. The sample flow of approximately $12 \mathrm{~L} \mathrm{~min}^{-1}$ was continuously monitored.

\subsection{Instrumentation}

\subsubsection{Meteorological parameters and state parameters}

Aircraft state parameters and meteorological measurements were performed with an AIMMS-20 manufactured by Aventech Research Inc. at a very high sampling frequency ( $>40 \mathrm{~Hz}$ ). The AIMMS-20 consists of three modules: (1) the air data probe that measures the three-dimensional (3-D) aircraft-relative flow vector (true air speed, angle-of-attack and sideslip) and turbulence with a 3-D accelerometer; furthermore, temperature and humidity sensors are contained within this unit and provide an accuracy and resolution of 0.30 and $0.01^{\circ} \mathrm{C}$ for temperature and 2.0 and $0.1 \%$ for relative humidity measurements; (2) an inertial measurement unit that consists of three gyros and three accelerometers providing the aircraft angular rate and acceleration; (3) A Global Positioning System for aircraft 3-D position and inertial velocity. Horizontal and vertical wind speeds were measured with accuracies of 0.50 and $0.75 \mathrm{~m} \mathrm{~s}^{-1}$, respectively. The high-frequency raw data were processed to $1 \mathrm{~Hz}$ resolution. Further details of the AIMMS including data processing can be found in Aliabadi et al. (2016a).

\subsubsection{Aerosol physical and chemical properties}

Particle number concentrations and particle size distributions were measured with a TSI 3787 water-based ultrafine condensation particle counter (UCPC), a Droplet Measurement Technology (DMT) Ultra-High Sensitivity Aerosol Spectrometer (UHSAS) and a Brechtel Manufacturing Incorpo- 
rated (BMI) scanning mobility system (SMS) coupled with a TSI 3010 condensation particle counter (CPC). The UCPC detected particle concentrations of particles larger than $5 \mathrm{~nm}$ in diameter with a time resolution of $1 \mathrm{~Hz}$. The flow rate was set to $0.6 \mathrm{~L} \mathrm{~min}^{-1}$. The particle concentrations measured by the UCPC are hereafter referred to as $N_{\text {tot }}$, noting as above that diffusional losses of particles smaller than $10 \mathrm{~nm}$ determine the lower limits of the $N_{\text {tot }}$ observations.

The BMI SMS was set to measure particle size distributions from 20 to $100 \mathrm{~nm}$ with a sample flow of $1 \mathrm{~L} \mathrm{~min}^{-1}$ and a sheath flow of $6 \mathrm{~L} \mathrm{~min}^{-1}$. The duration of one scan was $40 \mathrm{~s}$ with a $20 \mathrm{~s}$ delay time before each scan resulting in a time resolution of $1 \mathrm{~min}$. The UHSAS performed size distribution measurements from $70 \mathrm{~nm}$ to $1 \mu \mathrm{m}$ at a time resolution of $1 \mathrm{~Hz}$ with a sample flow rate of $55 \mathrm{~cm}^{3} \mathrm{~min}^{-1}$. Details of the calibrations and instrument inter-comparisons performed prior to and during the campaign are described in detail in Leaitch et al. (2016).

CCN were measured with a DMT CCN counter (CCNC). The CCNC was operated behind a constant pressure inlet that was set to $650 \mathrm{hPa}$. The nominal supersaturation was held constant at $1 \%$. Calibrations prior to and during the campaign (for details see Leaitch et al., 2016) showed that a nominal supersaturation of $1 \%$ at the reduced pressure translated into $0.6 \%$ effective supersaturation.

Cloud droplet sizes from 2 to $45 \mu \mathrm{m}$ were measured using a wing mounted particle measuring system FSSP 100. In this study these data are only used to identify periods when the aircraft was flying in clouds. To avoid possible artefacts produced from shattering of cloud droplets at the aerosol inlet, data from in-cloud times are discarded for the purposes of this study.

A DMT single-particle soot photometer (SP2) was deployed to measure refractory black carbon (rBC) number and mass concentrations. We refer to $\mathrm{rBC}$ mass concentrations as an indication of pollution influence. Calibrations with Aquadag soot were performed prior to and during the campaign. The lower size limit of detection of $\mathrm{rBC}$ particles by the SP2 was approximately $80 \mathrm{~nm}$.

Sub-micron aerosol composition was measured with an Aerodyne high-resolution time-of-flight aerosol mass spectrometer (HR-ToF-AMS; e.g. DeCarlo et al., 2006). A detailed description of the instrument is found in Willis et al. (2016). The main purpose of the instrument was to measure non-refractory particulate matter such as sulfate, nitrate, ammonium, methane sulfonic acid (MSA) and the sum of organics. Detection limits were 0.009, 0.008, 0.004, 0.005 and $0.08 \mu \mathrm{g} \mathrm{m}^{-3}$, respectively, for a $30 \mathrm{~s}$ averaging time.

\subsubsection{Trace gases}

Carbon monoxide (CO) was measured with an Aerolaser ultra-fast carbon monoxide monitor model AL 5002 based on vacuum ultraviolet (VUV) fluorimetry, employing the excitation of $\mathrm{CO}$ at $150 \mathrm{~nm}$. In situ calibrations were performed during flight at regular intervals (15-30 min) using a National Institute of Standards and Technology (NIST) traceable CO standard with zero water vapour concentration. $\mathrm{CO}$ mixing ratios were used as a relative indicator of aerosol influenced by pollution sources.

Water vapour $\left(\mathrm{H}_{2} \mathrm{O}\right)$ measurements were based on infrared absorption using a LI-7200 enclosed $\mathrm{CO}_{2} / \mathrm{H}_{2} \mathrm{O}$ Analyzer from LI-COR Biosciences $\mathrm{GmbH}$. The measurement uncertainty is $\pm 15 \mathrm{ppm}_{v} . \mathrm{H}_{2} \mathrm{O}$ mixing ratios were used to calculate relative humidity with pressure and temperature measured by the AIMMS-20.

\subsection{Data analysis and nomenclature of particle size data}

All particle data were averaged to $1 \mathrm{~min}$ intervals to match the time resolution of the BMI SMS. Particle concentrations within different size intervals were calculated. The notation $N_{\mathrm{a}-\mathrm{b}}$ is used; "a" gives the lower limit and "b" the upper limit of the calculated size interval. The BMI SMS was used to determine concentrations of particles from 20 to $90 \mathrm{~nm}$ in diameter, and concentrations of particles larger than $90 \mathrm{~nm}$ in diameter were determined by the UHSAS. If the size interval is expressed as $N_{>\mathrm{a}}$ the upper limit is given by the detection limit of the UHSAS $(1 \mu \mathrm{m})$. Additionally, particle concentrations from 5 to $20 \mathrm{~nm}$ (short: $N_{5-20}$ ) were obtained by subtracting particle concentrations measured by the BMI SMS and by the UHSAS from the $N_{\text {tot }}$ as determined by the CPC. The $N_{5-20}$ are also referred to as ultrafine particles (UFP) in this study and may be indicative of newly formed particles. Willis et al. (2016) showed that for this environment particles were able to grow to $50 \mathrm{~nm}$ low above the open water over approximately $1 \mathrm{~h}$, which means that the growth from 1 to $10 \mathrm{~nm}$ can occur over approximately $1 \mathrm{~min}$ or less, justifying our use of instruments that are sensitive to $5 \mathrm{~nm}$ particles and larger. For the concentration range of $N_{5-20}$ particles (less than $2000 \mathrm{~cm}^{-3}$ ), it requires more than $30 \mathrm{~h}$ for the concentration of $10 \mathrm{~nm}$ particles to be reduced by coagulation to a concentration of $500 \mathrm{~cm}^{-3}$ (Agranovski 2010).

In order to obtain vertical profiles the data were averaged within altitude intervals. An average profile for a single flight was obtained by binning all data from the respective flight into altitude intervals of $100 \mathrm{~m}$ starting at the lowest flight altitude. In addition to data obtained during vertical profile flights, data acquired while flying at a constant level were also included. Average profiles containing data from more than one flight were calculated by averaging the respective single flight profiles.

Average size distributions were obtained by simply averaging each bin for the desired time and altitude range. The size distributions measured by the BMI SMS were used for particle sizes from 20 to $90 \mathrm{~nm}$, and the distributions at larger sizes are taken from the UHSAS. All particle concentrations are expressed for ambient pressure conditions, i.e. they have not been adjusted to standard temperature and pressure con- 


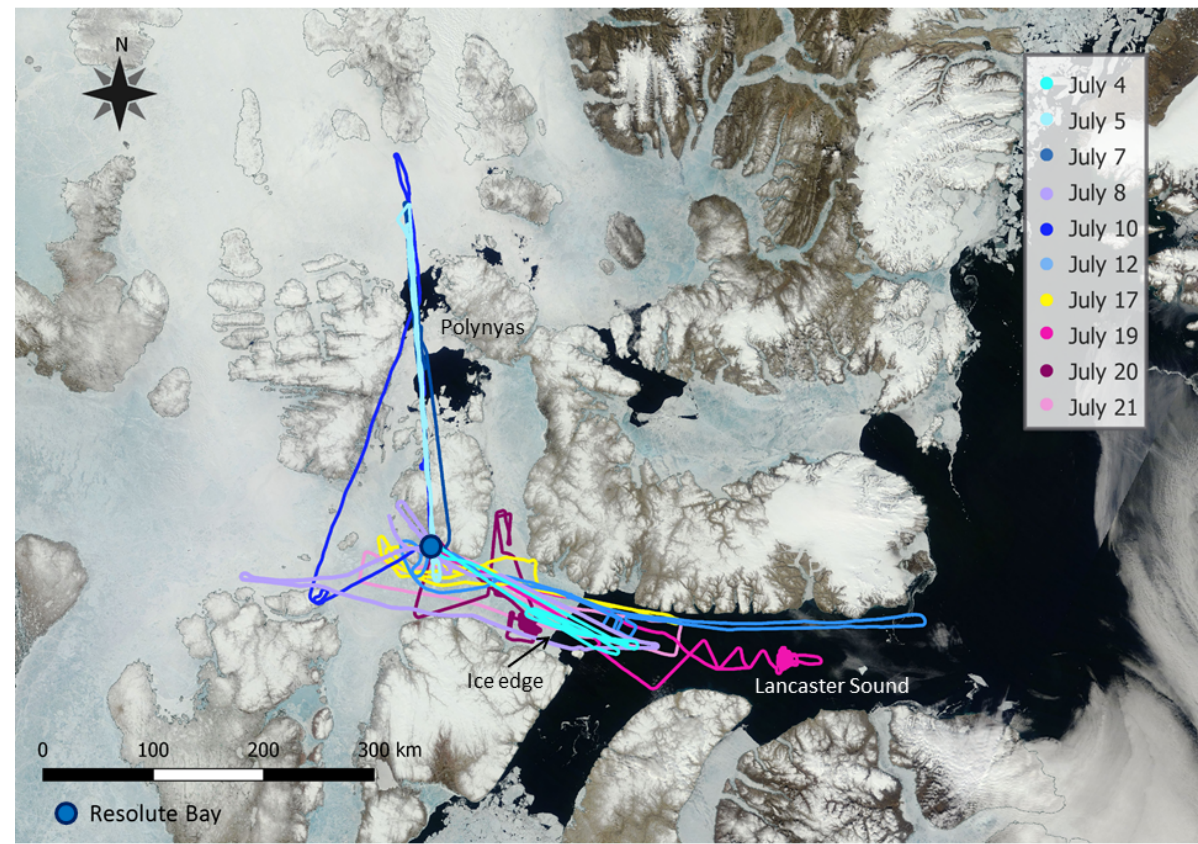

Figure 1. Compilation of all flight tracks plotted on a satellite image from 4 July 2014. The image is taken from https://earthdata.nasa.gov/ labs/worldview.

ditions. The $N_{5-20}$ referred to as UFP are added to the size distributions as additional bin assuming a bin width of $15 \mathrm{~nm}$ (from 5 to $20 \mathrm{~nm}$ ) with a mid-diameter of $12 \mathrm{~nm}$.

\subsection{FLEXPART-WRF Simulations}

We used FLEXPART-WRF (Brioude et al., 2013; website: http://flexpart.eu/wiki/FpLimitedareaWrf) simulations run backwards in time to analyse the origins of air masses sampled along the flight tracks. FLEXPART-WRF is a Lagrangian particle dispersion model based on FLEXPART (Stohl et al., 2005). Meteorological information is obtained from the Weather Research and Forecasting (WRF) model (Skamarock et al., 2005). FLEXPART-WRF outputs retroplume information such as the residence time of air (over a unit area) prior to sampling. Residence times were integrated over the entire atmospheric column and 7 days backwards in time. FLEXPART-WRF was run in two ways. First, one FLEXPART-WRF was completed for each flight using particle releases every $2 \mathrm{~min}$ along the flight track $(100 \mathrm{~m} \times 100 \mathrm{~m} \times 100 \mathrm{~m}$ centred on the aircraft location) to produce potential emissions sensitivities that represent the average air mass origin for each flight. Second, separate runs were completed for points (every $10 \mathrm{~min}$ ) along the flight track $(100 \mathrm{~m} \times 100 \mathrm{~m} \times 100 \mathrm{~m}, 60 \mathrm{~s}$ release duration $)$ in order to study different air masses measured during the same flight. A more detailed description of the model as used for NETCARE 2014 is provided by Wentworth et al. (2016).

\subsection{Study area and flight tracks}

From 4 to 21 July 201411 flights were conducted out of Resolute Bay $\left(74.7^{\circ} \mathrm{N}, 95.0^{\circ} \mathrm{W}\right)$. In Fig. 1 a compilation of all flight tracks on a satellite image is shown. The satellite picture was taken on 4 July 2014 and reflects the situation of the region during period I (4 to 12 July). Resolute Bay proved to be an ideal location for this study as we had access to both open ocean and ice-covered regions. Additionally, two polynyas were located north of Resolute Bay within the reach of our aircraft. Flights ranged between 4 and $6 \mathrm{~h}$. The flights covered two main areas: Lancaster Sound east of Resolute Bay and the area north of Resolute Bay, where two polynyas were located. The flights south of Resolute Bay in Lancaster Sound concentrated around the ice edge.

The ice/water coverage visible on the satellite picture is representative for the area during the first period. As can be seen, the ice edge was situated about $150 \mathrm{~km}$ east of Resolute Bay. It is clearly visible in the satellite image as a sharp line. The transition from a completely ice-covered region to open ocean was very abrupt during the first period. Only after a period of bad weather with high winds did the ice edge become less clear, and the region starting about $80 \mathrm{~km}$ east of Resolute Bay to about $200 \mathrm{~km}$ east was covered by fractured ice.

Roughly $50 \%$ of the flight time was within the inversion layer, and $50 \%$ was in the free troposphere conducting altitude profile flights. A considerable amount of time was spent at $2800 \mathrm{~m}$ as this was the preferred altitude when travelling to a certain area. When clouds were present, the aircraft sam- 

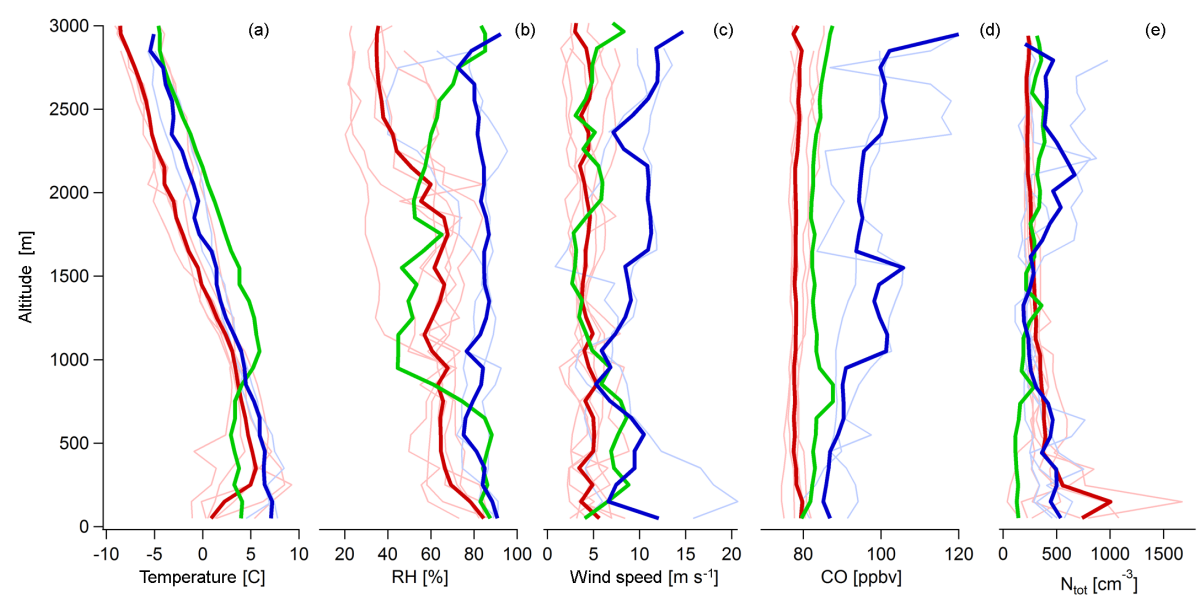

Figure 2. Median temperature, relative humidity $(\mathrm{RH})$, wind speed, $\mathrm{CO}$ mixing ratio and $N_{\text {tot }}$ profiles for the Arctic air mass period (dark red), the transition day (dark green), and the southern air mass period (dark blue). Median profiles for each flight are plotted in the background in the corresponding light colours.

pled them by slant profiling through the cloud in the case that clouds were above the boundary layer, or in the case clouds were within $200 \mathrm{~m}$ of the surface, by descending into the cloud as low as possible. Aerosol observations while inside cloud are excluded from the analysis here due to potential artefacts from droplets shattering on the outside inlet.

\section{Meteorological and atmospheric conditions}

Meteorological conditions changed over the course of the campaign. Similar conditions were encountered during the first part of the campaign (4-12 July, 6 flights), referred to as the "Arctic air mass period" because air masses from within the Arctic dominated and the atmosphere showed structures typical for the Arctic, such as a low boundary layer height with thermally stable conditions, indicated by a near-surface temperature inversion and frequent formation of low-level clouds. At this time Resolute Bay was under the influence of high-pressure systems. Clear sky with few or scattered clouds and low wind speeds dominated. Conditions changed starting from 13 July when the region was influenced by troughs of a low-pressure system located to the west above Beaufort Sea, which eventually passed through Resolute Bay on 15 July bringing along humidity, precipitation and fog. Intense fog and low visibility impeded flying from 13 to 16 July. A short good weather window in which the fog dissipated permitted flying again on 17 July (referred to as "transition day"; one flight) just before Resolute Bay came under influence of a pronounced low-pressure system located to the south with its centre around King William Island $\left(69.0^{\circ} \mathrm{N}, 97.6^{\circ} \mathrm{W}\right)$. The last campaign days (referred to as "southern air mass period", three flights) were characterised by the influence of this pronounced low-pressure system bringing air masses from the south and providing higher wind speeds, an overcast sky and occasional precipitation.

Vertical profiles of median temperature, relative humidity (RH), wind speed, CO and $N_{\text {tot }}$ (Fig. 2) illustrate median atmospheric conditions during the measurement flights. Prominent features representing the trend of each period and reflecting the general meteorological situation will be described here, with details discussed in the respective sections. The Arctic air mass period was characterised by frequent thermally stable conditions within the near-surface layer, representing typical conditions during the Arctic summertime (Aliabadi et al., 2016a; Tjernström et al., 2012). The median temperature profiles show that on average the boundary layer reached up to $\sim 300 \mathrm{~m}$ with a temperature increase of about $5^{\circ} \mathrm{C}$. In this paper we will refer to this part of the atmosphere as the boundary layer (BL) and to the air masses above as the free troposphere (FT). A BL height of $300 \mathrm{~m}$ corresponds well to the boundary layer height of $275 \mathrm{~m} \pm 164 \mathrm{~m}$ estimated by (Aliabadi et al., 2016a) using the method of bulk Richardson number (Aliabadi et al., 2016b) with a critical bulk Richardson number of 0.5 , using data from radiosondes launched at Resolute Bay and the Amundsen icebreaker, which also performed research operations in Lancaster sound during the campaign period.

Within the BL, particle concentrations spanned over a wide range of concentrations (max $N_{\text {tot }}: \sim 10000$; median values: $\sim 150$ to $\sim 1700 \mathrm{~cm}^{-3}$ ). The highest $N_{\text {tot }}$ occurred during the Arctic air mass period, while $N_{\text {tot }}$ was constantly low within the lower atmosphere on the transition day. Median temperatures near the surface ranged from -1 to $5{ }^{\circ} \mathrm{C}$ during the Arctic air mass period, largely depending on the terrain below (e.g. ice or open water) and were clearly higher when the southern air masses arrived (e.g. at the "surface": 4 and $7{ }^{\circ} \mathrm{C}$, respectively) and, if present, the BL was less pronounced. The higher temperatures co- 
incide with the influence of low-pressure systems bringing warmer air masses from the west and south, and additional higher wind speeds providing a better mixing of the atmospheric layers ( $5.6 \mathrm{~m} \mathrm{~s}^{-1}$ vs. $12 \mathrm{~m}^{-1}$ near the surface). $\mathrm{CO}$ mixing ratios were extremely low during the Arctic air mass period (median: $78.3 \mathrm{ppb}_{v}$ ) and on the transition day (median: $83.4 \mathrm{ppb}_{v}$ ) indicating pristine air masses that had not recently been affected by pollution or biomass burning sources. During the southern air mass influence, $\mathrm{CO}$ mixing ratios clearly increased (median: $95.0 \mathrm{ppb}_{v}$ ) confirming a change in air mass and suggesting possible influences by pollution sources and wild fires in the North West Territories (Fig. S2 in the Supplement). Relative humidity profiles show that the near-surface layer of the atmosphere was very moist with $\mathrm{RH}>80 \%$ during all periods.

\section{Results and discussion}

\subsection{Ultrafine particle events}

\subsubsection{Frequency of ultrafine particle events}

Throughout the campaign we observed large variability in particle concentrations (Fig. 3). We observed not only very clean air masses with $N_{\text {tot }}$ of a few tens of $\mathrm{cm}^{-3}$ (with the lowest $1 \mathrm{~s}$ value of $1 \mathrm{~cm}^{-3}$ ), but also concentrations as high as a few thousands per $\mathrm{cm}^{-3}$ (with the highest value of $10000 \mathrm{~cm}^{-3}$ ). The highest and lowest concentrations were measured within the BL (Fig. 3b). Above the BL (Fig. 3b) particle concentrations were relatively constant where $60 \%$ of the time concentrations were between 200 and $300 \mathrm{~cm}^{-3}$ (for a discussion of the average size distribution see Sect. 4.1.2-4.1.4). Especially during the Arctic air mass period (Fig. 2) the atmosphere was characterised by a strong contrast between the BL and the FT.

UFP were very frequently present within the BL in high concentrations (Fig. 3c). Here we refer to "bursts" of particles as a sudden and relatively large increase in $N_{5-20}$. concentrations suddenly rising from tens of $\mathrm{cm}^{-3}$ to several hundreds and thousands $\mathrm{cm}^{-3}$. This may reflect inhomogeneities in the UFP formation process or reflect the aircraft flying in and out of areas of high UFP concentrations. Bursts of $N_{5-20}>2000 \mathrm{~cm}^{-3}$ were observed over polynyas, which were consistent with previous observations (Leaitch et al., 1984, 1994), in Lancaster Sound and south of Resolute Bay. The $N_{5-20}$ was higher than $200 \mathrm{~cm}^{-3}$ during $65 \%$ of the time. Indeed, high $N_{\text {tot }}$ was mainly driven by UFP (as can be seen by comparison of black dots indicating high $N_{\text {tot }}$ in Fig. $3 \mathrm{c}$ and high UFP in Fig. 3d). Whenever $N_{\text {tot }}$ is greater than $2000 \mathrm{~cm}^{-3}$, UFP was larger than $1000 \mathrm{~cm}^{-3}$. This is also illustrated by the ratio of UFP/ $N_{\text {tot }}$ (Fig. 3e). A ratio of zero means that no UFP were present, while a ratio of 1 means that only UFP were present. Within the boundary layer $32 \%$ of the time the size distribution was dominated by UFP (ratio > 0.5).

The frequent presence of UFP agrees well with other studies made during the Arctic summertime at several locations, such as at the ground stations in Ny Alesund and Zeppelin (Ström et al., 2009; Tunved et al., 2013), at Alert (Leaitch et al., 2013), and from ship-based observations (Chang et al., 2011; Covert et al., 1996; Heintzenberg et al., 2006). However, such a frequent presence of an UFP mode $(65 \%$ of the time $>200 \mathrm{~cm}^{-3}$ ) in the $\mathrm{BL}$ is unique to this study. Possible reasons for the higher occurrence of UFP might be the combination of the proximity of open ocean (providing a source of UFP or precursor gases), favourable meteorological conditions (sunny weather, inversion layer with cloud formation) and very clean air masses with low condensation sinks. Also, since observations of UFP were one focus of this study, the fractional occurrence of the UFP mode may be biased slightly high due to longer sampling times associated with UFP occurrence. Calm weather conditions may have been another factor. The highest concentrations of UFP were measured at lower wind speeds $\left(<5 \mathrm{~m} \mathrm{~s}^{-1}\right.$; Fig. S1), while lower UFP concentrations $\left(1000 \mathrm{~cm}^{-3}\right)$ were found at higher wind speeds $\left(>12 \mathrm{~m} \mathrm{~s}^{-1}\right)$ suggesting a dilution effect of the wind. Such a dilution effect implies proximity to the source.

In the following sections, the vertical distribution of UFP and the size distributions are discussed in relation to meteorological conditions during the three distinct periods that characterised this campaign.

\subsubsection{Arctic air mass period: 4 July to 12 July}

During this first period the study area was under the influence of a high-pressure system. As illustrated by FLEXPARTWRF results (Fig. 4a and b), air masses were either coming from the north extending to the east in the Arctic Ocean or from the east passing over the open ocean in Lancaster Sound and Baffin Bay. Both examples indicate that air masses resided within the Arctic region at least 5 days prior to sampling. This is true for all flights during this period. The very low CO mixing ratios (78 $\mathrm{ppb}_{v}$; see Fig. 2) and average BC mass concentrations of $3 \mathrm{ng} \mathrm{m}^{-3}$ (not shown) confirm that air masses were very clean and without recent influence from pollution sources. As discussed in Sect. 3, temperature profiles indicate thermally stable conditions in the lowest layers with near-surface temperature inversions. During almost all vertical profiles, we observed temperature inversions of about $4-6{ }^{\circ} \mathrm{C}$ near the surface. Such an atmospheric structure, i.e. a shallow boundary layer, is typical for the Arctic summertime (e.g. Aliabadi et al., 2016a; Tjernström et al., 2012).

The Arctic air mass period was characterised by a very sharp contrast between the BL and the FT in terms of particle number concentrations and sizes (Fig. 5). The BL was characterised by a prominent layer of UFP from the surface to about $300 \mathrm{~m}$ with the highest concentrations closest to the 
(a)

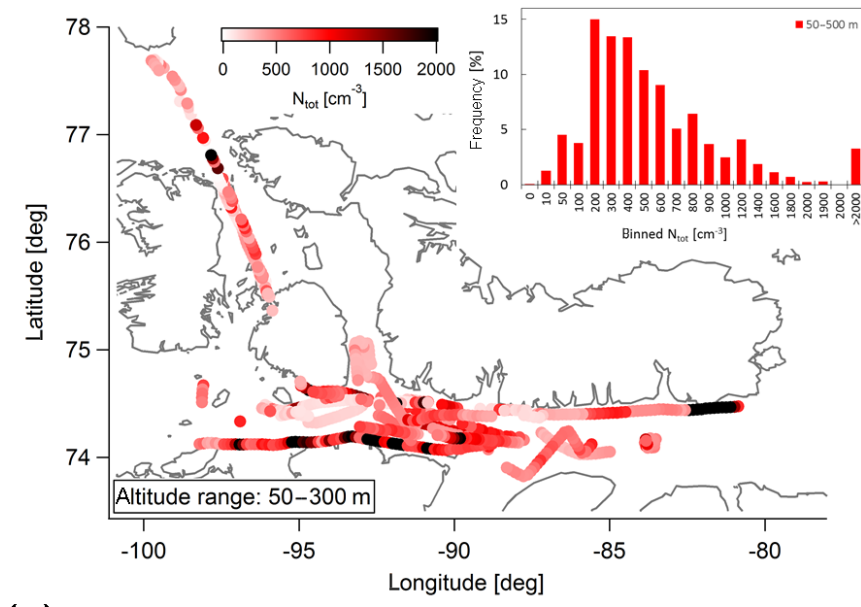

(c)

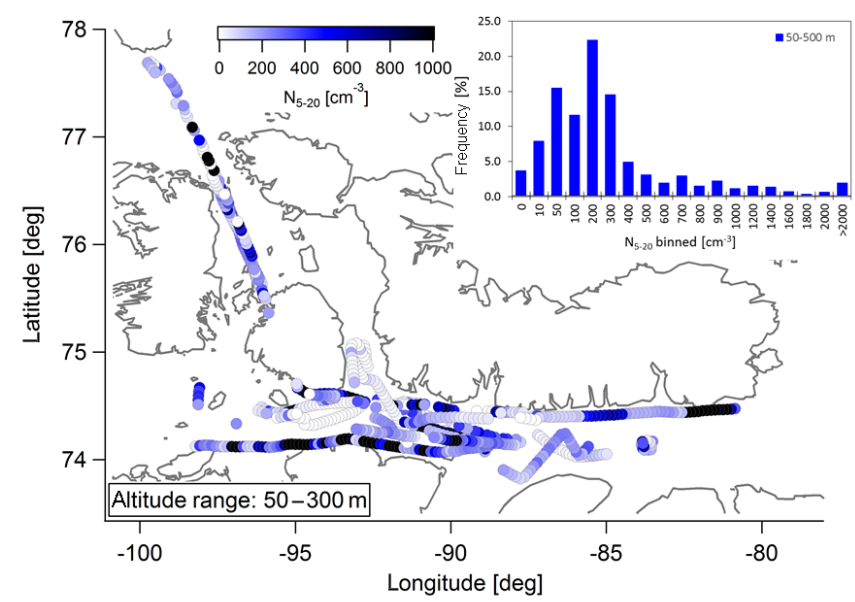

(b)

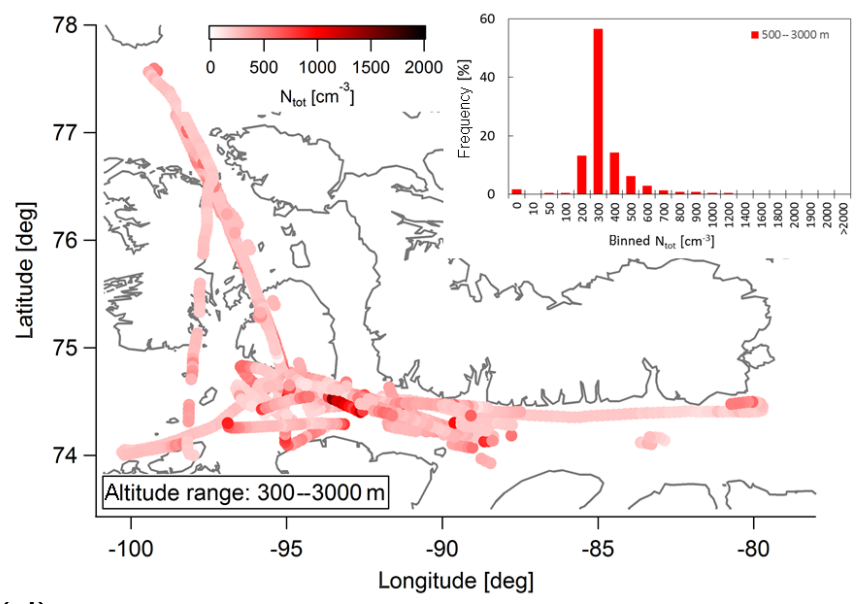

(d)

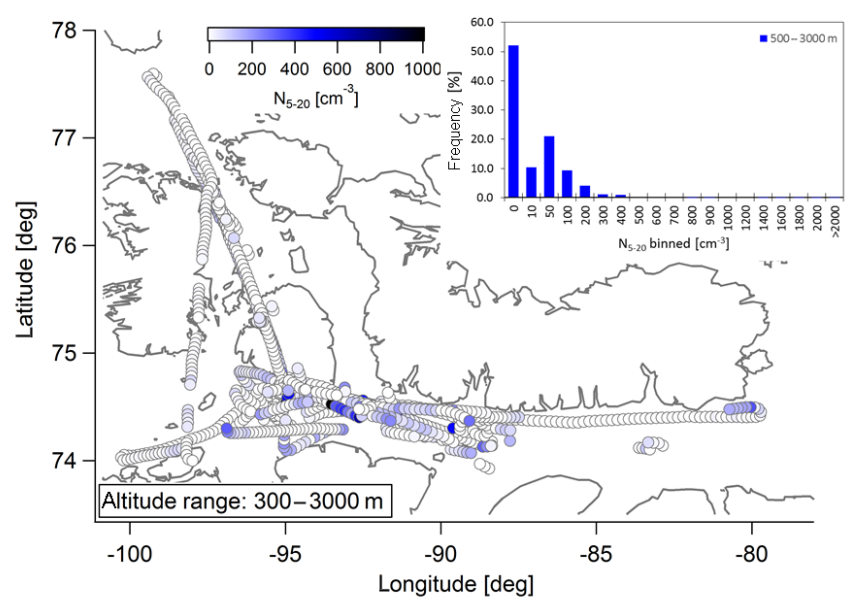

(e)

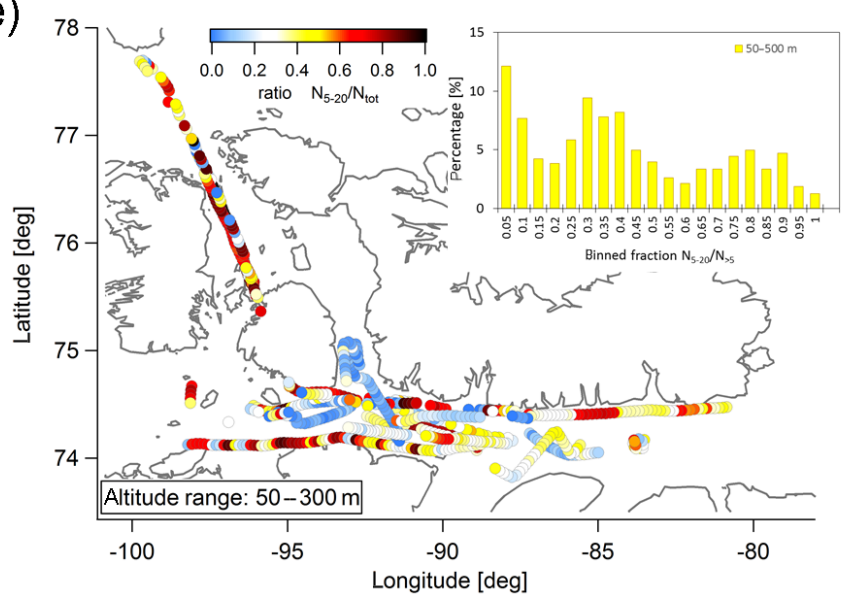

Figure 3. Flight tracks colour coded by particle concentrations. (a) Flight tracks within the boundary layer (50-300 m) colour coded by $N_{\text {tot. }}$ (b) Flight tracks within the free troposphere $\left(300-3000 \mathrm{~m}\right.$ ) colour coded by $N_{\text {tot }}$. (c) Flight tracks within the boundary layer (50$300 \mathrm{~m}$ ) colour coded by UFP. (d) Flight tracks within the free troposphere (300-3000 m) colour coded by $N_{5-20}$. (e) Flight tracks within the boundary layer $(50-300 \mathrm{~m})$ colour coded by the ratio of $N_{5-20} / N_{\text {tot }}$. 
(a) Arctic air mass period - July 8

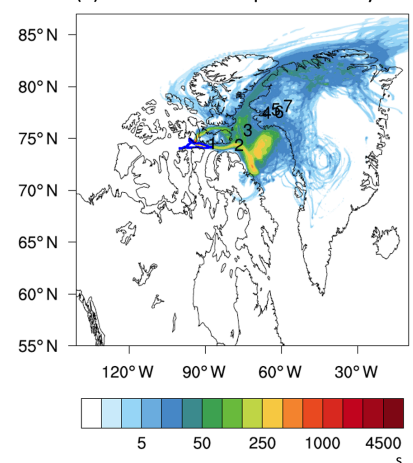

(d) Southern air mass influence - July 19

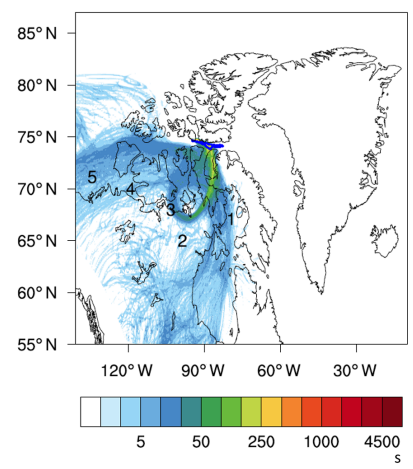

(b) Arctic air mass period - July 10

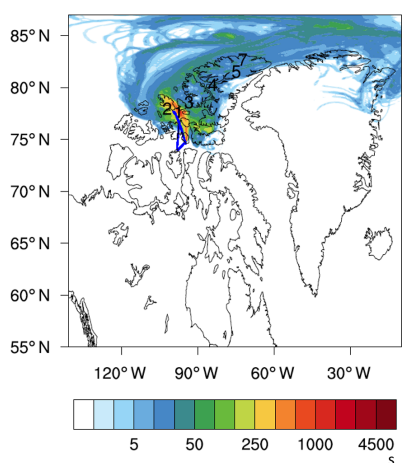

(e) Southern air mass influence - July 21

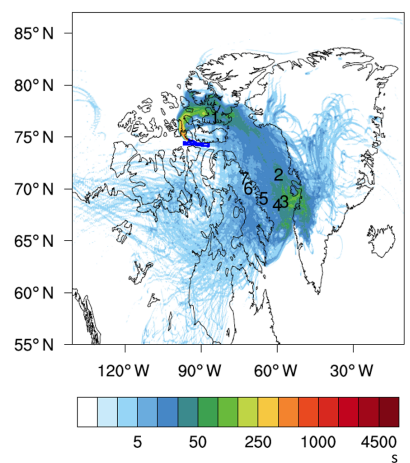

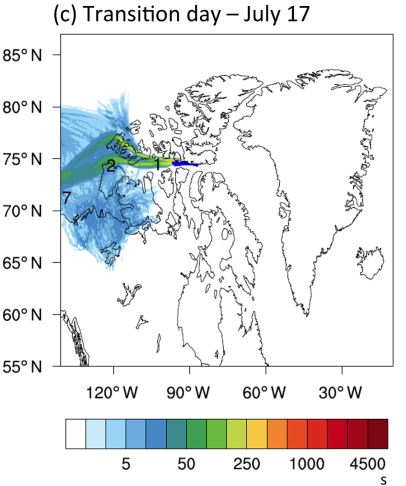

Figure 4. FLEXPART-WRF potential emissions sensitivities for each flight (using particle releases every 2 min along the flight track) that illustrate transport regimes during different periods of the campaign. The colour code indicates the residence time of air in seconds and the numbers represent the position of the plume centroid location in days prior to release (days 1-7).

surface (Fig. 5a). The height of the UFP layer coincides with the average height of the temperature inversion for this period (see temperature profile Fig. 2) and indicates that air masses were stably layered limiting exchange with the FT. This is supported by the observed lower turbulent mixing (i.e. turbulent kinetic energy) from boundary layer to the free troposphere during the campaign (Aliabadi et al., 2016a).

During this period we measured the highest concentrations of UFPs with the $1 \mathrm{~min}$ average up to $5300 \mathrm{~cm}^{-3}$. On a typical flight several bursts (see Sect. 4.1.1) of high UFP concentrations were encountered in the BL. Particle bursts lasted from a few seconds to several minutes, corresponding to a spatial extent of several hundreds of metres to dozens of kilometres. The large spatial variability is also illustrated by the frequency distribution of UFP in the BL shown in Fig. 5c; $40 \%$ of the time concentrations of UFP were larger than $200 \mathrm{~cm}^{-3}, 11 \%$ of the time larger than $1000 \mathrm{~cm}^{-3}$ and $3 \%$ of the time even larger than $2000 \mathrm{~cm}^{-3}$. Particle concentrations in the FT are relatively uniform, and concentrations of UFP were less than $50 \mathrm{~cm}^{-3}$ up to $1200 \mathrm{~m}$ and $\sim 10 \mathrm{~cm}^{-3}$ above.

The average $N_{20-40}$ is similar to the UFP, showing a maximum in its concentration at the same altitude. The concentrations of larger particles $\left(N_{>40}, N_{>80}, N_{>150}\right)$ are much lower in the clean BL (surface areas of $\sim 5 \mu \mathrm{m}^{2} \mathrm{~m}^{-3}$ and lower). However, the $N_{>40}$ and $N_{>80}$ increase from the lowest altitude to the next averaged altitude, consistent with the increase in the UFP and $N_{20-40}$. These results suggest that some of the UFP experienced growth to sizes of $20-80 \mathrm{~nm}$ within a few hours, as demonstrated by Willis et al. (2016). Within the FT particle concentrations were surprisingly uniform and concentrations of UFP were less than $50 \mathrm{~cm}^{-3}$ up to $1200 \mathrm{~m}$ and $\sim 10 \mathrm{~cm}^{-3}$ above $1200 \mathrm{~m}$.

In Fig. 5b, the median size distribution shows that increases in UPF in the BL were frequent. The average size distribution shows that at times higher concentrations of particles extended up to about $80 \mathrm{~nm}$, consistent with the suggestion above that some UFP particles experienced growth to larger sizes. A relevant case will be discussed in Sect. 4.3. Occasionally a mode of particles larger than $400 \mathrm{~nm}$ was present in the BL over open water (see Sect. 4.2), which was likely the product of primary oceanic emissions.

\subsubsection{Transition day on 17 July}

17 July marks the transition from dominance by Arctic air masses to a more distant influence from southern air masses. The transition day consists of only one flight in the area of Lancaster Sound, during which low concentrations of particles larger than $20 \mathrm{~nm}$ were observed below $600 \mathrm{~m}$; e.g. $N_{>} 40$ 
(a)

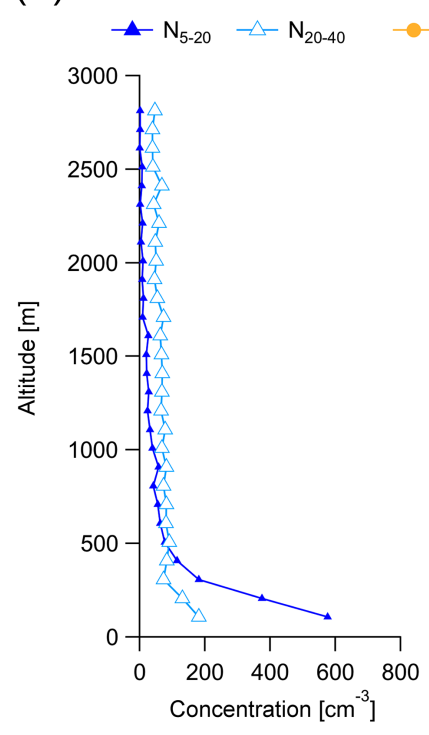

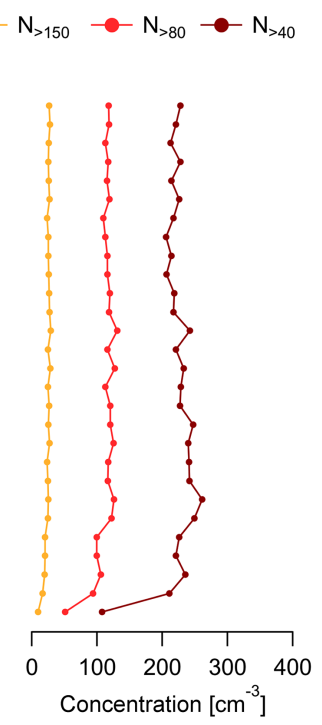

(b)

(c)
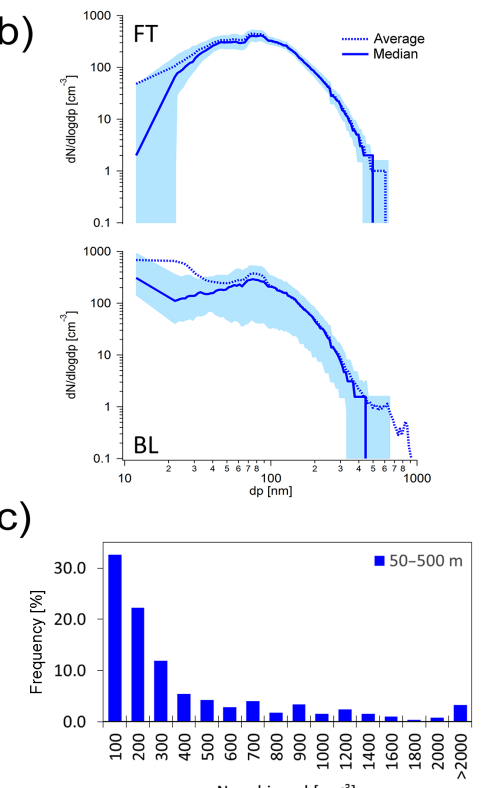

Figure 5. Average particle concentration data during the Arctic air mass period. (a) Average vertical profiles of $N_{5-20}, N_{20-40}, N_{>40}, N_{>} 80$ and $N_{>150}$. (b) Average (solid line) and median (dashed line) size distribution within the BL and the FT. The light blue area represents the $25-75$ th \% percentile range. (c) Frequency distribution of the occurrence of UFP illustrates the large variability of the UFP concentrations within the BL.

ranged from 60 to $100 \mathrm{~cm}^{-3}$; see Fig. 6. The deeper layer of lower concentrations may have been a result of cloud processing and scavenging. During the days prior to this flying was impossible because of intense fog and cloud at Resolute Bay. A different transport regime may also have contributed to this situation. On this day the low-pressure system situated to the west was bringing air masses from the west along the Canadian and Alaskan coastline (Fig. 4c). The temperature profile shows an inversion between 650 and $1000 \mathrm{~m}$ possibly indicating a change in air mass. $\mathrm{CO}$ mixing ratios $\left(83 \mathrm{ppb}_{v}\right)$ and $\mathrm{BC}$ mass concentrations $\left(3 \mathrm{ng} \mathrm{cm}^{-3}\right)$ were also quite low indicating mostly Arctic background conditions.

On this day, occasional bursts of UFP up to 1400$1900 \mathrm{~cm}^{-3}$ were observed within the boundary layer (Fig. 6b). UFP of $200 \mathrm{~cm}^{-3}$ or more were observed about $20 \%$ of the time (Fig. $6 \mathrm{c}$ ), and the average concentration was $240 \mathrm{~cm}^{-3}$ at the lowest level of the profile (Fig. 6a). Concentrations of larger particles $\left(N_{>40}, N_{>80}, N_{>150}\right)$ increased sharply at about $700 \mathrm{~m}$, coinciding with the temperature inversion. The very low concentrations of larger particles $\left(N_{>150}:<10 \mathrm{~cm}^{-3}\right)$ below the temperature inversion are very similar to the conditions encountered within the BL during the previous period. As above, the differences in the transition day below $700 \mathrm{~m}$ may have been due to a combination of fog/cloud scavenging and a change of air mass. Median and average size distributions indicate a minimum at around $65 \mathrm{~nm}$ that might be the result of cloud processing (Hoppel et al., 1994), consistent with the Arctic observations of Heintzenberg et al. (2006) and the activation diameters observed during this study (Leaitch et al., 2016).

\subsubsection{Southern air mass period: 19 July-21 July}

During this period the region was under the influence of a low-pressure system centred south of Resolute Bay. FLEXPART-WRF air mass trajectories (Fig. $4 \mathrm{~d}$ and e) indicate a prevalence of air masses from the south potentially affected by wild fires (see Fig. S2). At the beginning of this period on 19 July (Fig. 4d), air mass trajectories suggest the strongest influence from the south while towards the end of the period on 21 July (Fig. 4e) FLEXPART-WRF indicates that southern air masses mixed with air masses coming off Greenland. Near-surface temperatures were higher than during the previous periods (Fig. 2), and temperature inversions were less pronounced $\left(2-4^{\circ} \mathrm{C}\right)$ and not observed at all locations suggesting a less stable lower atmosphere. On 19 July we encountered the highest wind speeds in the BL $\left(16 \mathrm{~m} \mathrm{~s}^{-1}\right.$ within the near-surface layer and $20 \mathrm{~m} \mathrm{~s}^{-1}$ slightly above). Furthermore, RH was relatively high near the surface $(91 \%)$ and did not drop below $80 \%$ throughout the vertical atmosphere. CO mixing ratios were higher than during the prior periods suggesting that the air was at times influenced by pollution or biomass burning.

UFP were observed less frequently than during the Arctic air mass period and in lower concentrations (Fig. 7). Bursts of UFP above $1000 \mathrm{~cm}^{-3}$ occurred only at three locations, all during the flight on 21 July. Average UFP concentrations 
(a)

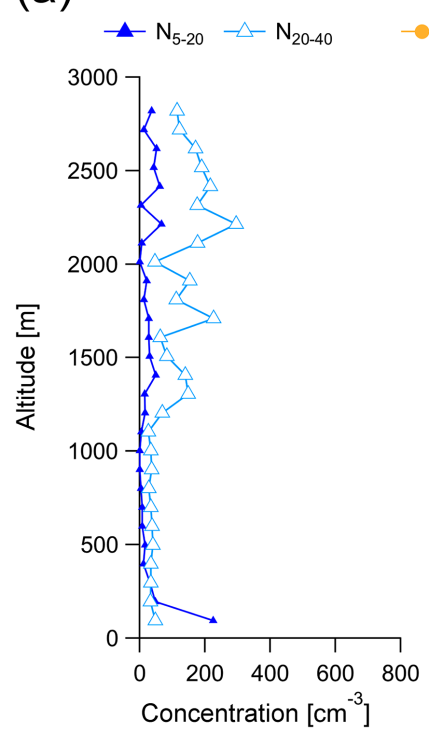

(b)

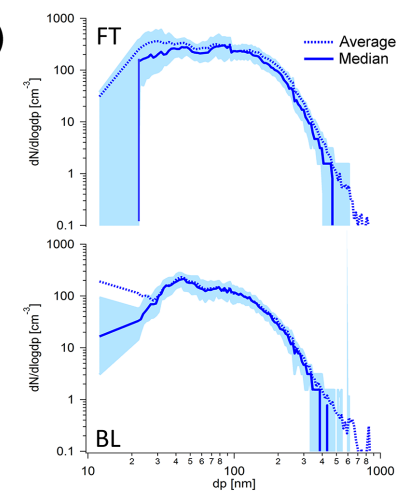

(c)

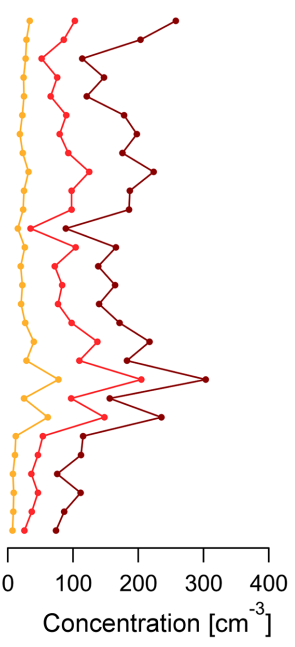

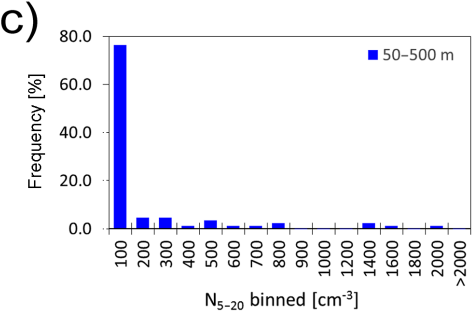

Figure 6. Average particle concentration data on the transition day. (a) Average vertical profiles of $N_{5-20}, N_{20-40}, N_{>40}, N_{>80}$ and $N_{>150}$. (b) Average (solid line) and median (dashed line) size distribution within the BL and the FT. The light blue area represents the 25-75th \% percentile range. (c) Frequency distribution of the occurrence of UFP illustrates the large variability of the UFP concentrations within the BL.

(a)

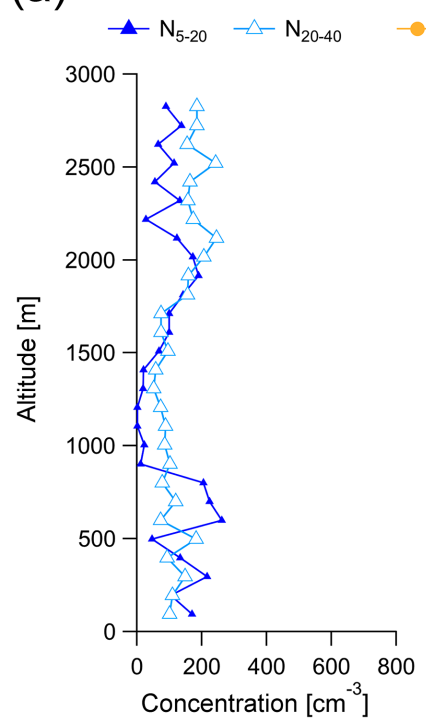

(b)

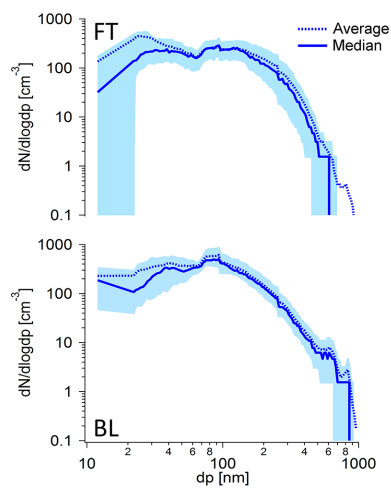

(c)

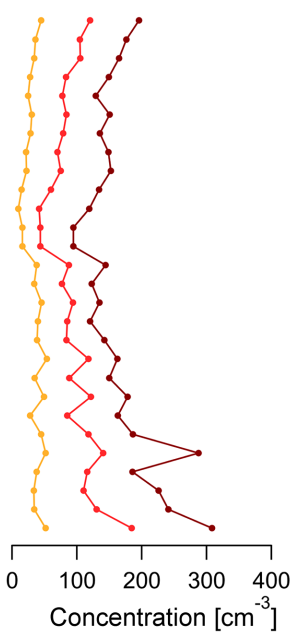

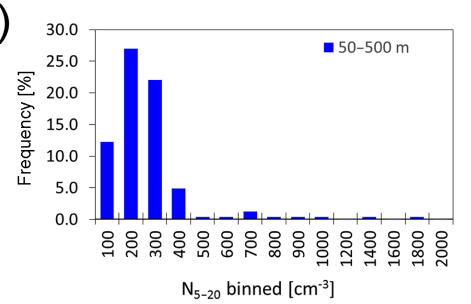

Figure 7. Average particle concentration data during the southern air mass period. (a) Average vertical profiles of $N_{5-20}, N_{20-40}, N_{>40}$, $N_{>80}$ and $N_{>150}$. (b) Average (solid line) and median (dashed line) size distribution within the BL and the FT. The light blue area represents the 25-75th \% percentile range. (c) Frequency distribution of the occurrence of UFP illustrates the large variability of the UFP concentrations within the BL. 

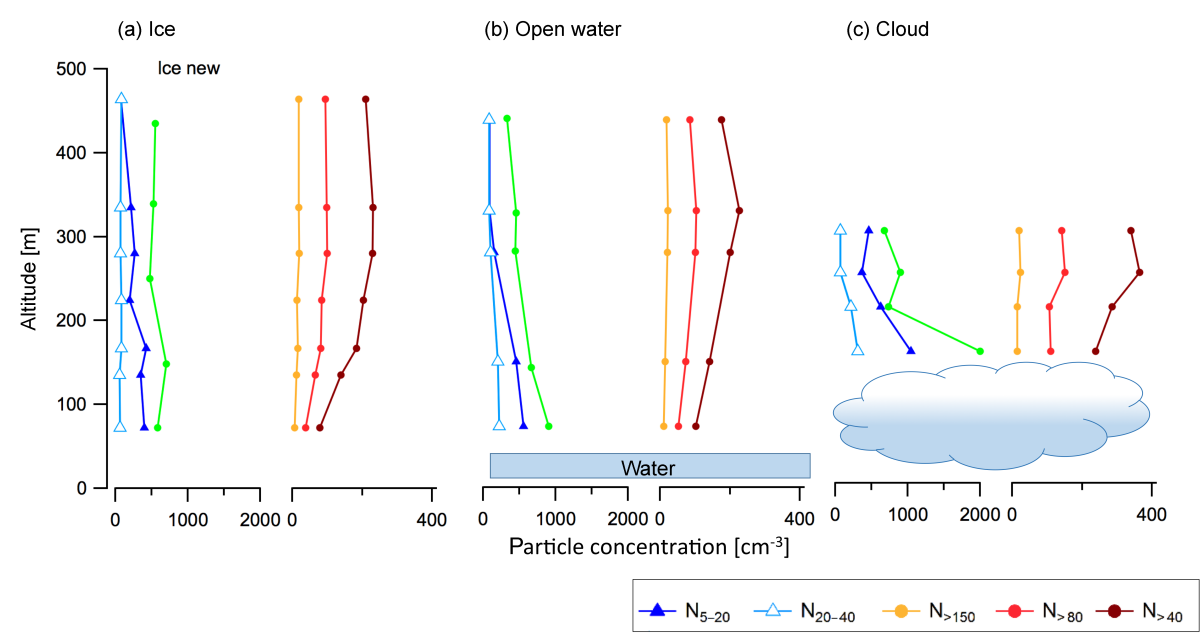

Figure 8. Average profiles of particle concentrations above ice, open water and cloud. The number of data points for each specific profile is 130 above water, 216 above cloud and 123 above water.

were only approximately $190 \mathrm{~cm}^{-3}$. UFP concentrations of $200 \mathrm{~cm}^{-3}$ or higher were detected $31 \%$ of the time below $300 \mathrm{~m}$ (Fig. 7c).

The southern air mass period clearly shows different aerosol characteristics within the near-surface layer than compared to the Arctic air mass period and the transition day. Average concentrations of particles larger than $40 \mathrm{~nm}$ were the highest within the boundary layer and decreased with altitude (Fig. 7a). This is in sharp contrast to the cleaner boundary layers observed before. Whereas concentrations of particles larger than $40 \mathrm{~nm}$ were $\sim 100 \mathrm{~cm}^{-3}$ and lower during both prior periods, they were as high as $300 \mathrm{~cm}^{-3}$ for this period. Even large accumulation-mode particles $\left(N_{>} 150\right)$ averaged $\sim 50 \mathrm{~cm}^{-3}$ (compared to $10 \mathrm{~cm}^{-3}$ for both previous periods). Moreover, both the median and average size distributions show a pronounced mode of particles larger than $500 \mathrm{~nm}$ within the BL (Fig. 7b). Primary emissions from the sea spray promoted by the higher surface wind speeds (see Fig. 2) are likely a factor contributing to the larger particles.

During the southern air mass period, three important factors had changed compared to both prior periods. (1) Air mass back trajectories had clearly shifted to the south and potentially transported emissions from wild fires located in the Northwest Territories (Fig. S2) into the region, which might mix into the boundary layer. (2) The Amundsen ice breaker was present in Lancaster Sound and acted as a local pollution source. (3) Wind speeds were higher and the ocean was visibly turbulent with breaking waves that might enhance primary oceanic aerosol emissions. The increased condensation sinks from these potential sources in combination with other factors (e.g. reduced sun light) and relatively low residence times of air masses within the boundary layer (compared to the Arctic air mass period) may explain the relatively low and infrequent concentrations of UFPs.
Within the FT the size distributions shows a bimodal character with a minima at $60-80 \mathrm{~nm}$, which may indicate the air masses experienced cloud processing. This is likely, given the presence of the low-pressure system bringing moister and warmer air masses. The bimodal size distribution is different from the average size distribution during the Arctic air mass period when drier air masses from within the Arctic dominated.

\subsection{UFP occurrence above ice vs. water}

We investigated the potential influence of different underlying water surfaces on the occurrence of UFP by examining in detail the time periods when we were flying at altitudes at or below $500 \mathrm{~m}$ during the Arctic air mass period. We distinguish between three water surfaces: ice-covered areas (including ice edge and ice covered with melt ponds), open ocean (including polynyas) and low-level clouds (including both cloud above water and cloud above ice). Here we point out that the case "cloud" does not include in-cloud flight times but only flight periods when above cloud top without actually entering the cloud (confirmed by a zero signal in a liquid cloud probe, FSSP100). An altitude of $500 \mathrm{~m}$ was chosen to include time periods when we were flying above low-level clouds and to capture mostly flights within the boundary layer where a local influence of the terrain below was likely. During the Arctic air mass period, there was a clear separation between ice and open water over Lancaster Sound with east of the ice edge completely ice free, where west of the ice edge the ocean was seamlessly covered by fast ice (see satellite picture in Fig. 1).

Each average profile above the different water surfaces exhibits unique features (Fig. 8). Above ice the highest concentrations of UFP (average: $400 \mathrm{~cm}^{-3}$ ) were found nearer the surface (70 m) and the $N_{\text {tot }}$ are slightly higher (580). In 

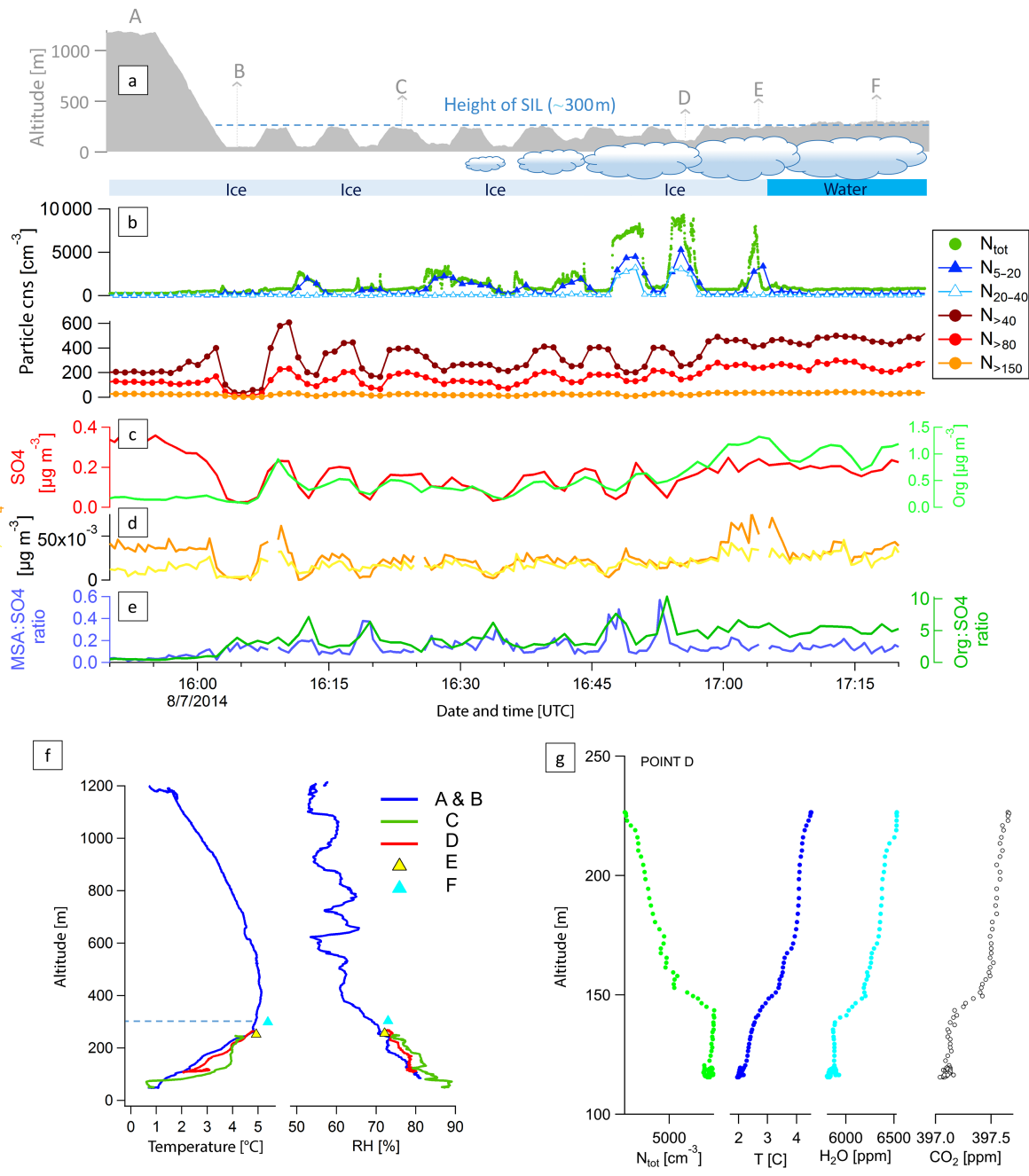

Figure 9. Case study from 8 July flight. Time series of flight altitude and illustration of the surface including cloud coverage (a), aerosol size (b) and chemical composition (c-e). (f) Vertical profiles of temperature and $\mathrm{RH}$ at locations A-F. (g) $N_{\text {tot }}$, temperature, $\mathrm{H}_{2} \mathrm{O}$ mixing ratio and $\mathrm{CO}_{2}$ profiles at location $\mathrm{D}$.

the BL over open water, the $N_{\text {tot }}$ and UFP number concentrations are 900 and $560 \mathrm{~cm}^{-3}$, respectively, and in the air just above cloud, the average $N_{\text {tot }}$ and UFP number concentrations are 2000 and $1040 \mathrm{~cm}^{-3}$, respectively. In the open water and cloud cases, the highest concentrations of ultrafine particles are at the point of measurement closest to the water surface. In the cloud case and open water case, the $N_{20-40}$ particles show an increase at the same time as the $N_{\text {tot }}$ and UFP suggesting that the UFP form and grow to larger sizes. This is not observed in the over-ice case, which suggests that some of the new particles could have formed elsewhere (e.g. over open water) and been transported over the ice, or that the growth rates over ice are slow. In all three cases, the largest particles show relatively smaller abundances at the lowest altitudes samples. An increased abundance of UFP at lower surface areas supports the hypothesis that UFP form via nucleation of precursor gases.

\subsection{Case study: 8 July}

The flight on 8 July provides a case study illustrating that the occurrence of UFP is confined to the BL suggesting a surface source of UFP and that the appearance of UFP is promoted by cloud. We consider the altitude dependence of the UFP within the BL in relation to air mass history and cloud.

On this flight we first flew out into Lancaster Sound west of Resolute Bay, turned around and descended into the BL above the ice. Here, we focus on the time period from 15:50 UTC (descent into the BL) to 17:20 UTC where we travelled from west to east and remained within the BL but stayed out of cloud as shown in Fig. 9; see also Fig. S2. The later part of the flight focused on in situ cloud properties and is discussed elsewhere (Leaitch et al., 2016). The weather was sunny with low-level clouds starting around $150 \mathrm{~km}$ over ice and west of the ice edge in Lancaster Sound. The clouds 
had formed over the water and were blown over the ice where they were dissipating (Leaitch et al., 2016). In the entire area the atmosphere was characterised by a surface temperature inversion extending vertically up to about $300 \mathrm{~m}$ with $\sim 1{ }^{\circ} \mathrm{C}$ near the surface and $\sim 5^{\circ} \mathrm{C}$ at $300 \mathrm{~m}$ and was accompanied by decreasing relative humidity (Fig. 9f). Local low-level winds were predominantly from the south to east and wind speeds were below $5 \mathrm{~m} \mathrm{~s}^{-1}$.

UFP were present throughout the BL with the highest concentrations at the lowest altitudes and decreasing concentrations towards the top of the BL (Fig. 9b). In contrast, larger particles (e.g. $N_{>} 40$ ) exhibit the opposite pattern, with lower concentrations at lower altitudes and higher concentrations at higher altitudes. Six locations from west to east (points A-F in Fig. 9a) are used to illustrate the changing aerosol characteristics. Location A is situated well above the BL and at this point no UFP were present (detailed size distributions are shown in Fig. S4). At location B, the point at which we first entered the BL, an UFP mode $\left(\sim 370 \mathrm{~cm}^{-3}\right)$ was present at $60 \mathrm{~m}$, while UFP concentrations were lower at slightly higher altitudes $\left(\sim 80 \mathrm{~cm}^{-3}\right.$ at $\left.230 \mathrm{~m}\right)$ such as at location C. At the lower altitudes the UFP concentrations gradually increased as we approached the ice edge. The most striking observation is the steep increase in particle concentrations at about $60 \mathrm{~km}$ west of the ice edge (location D), where UFP increased to above $4000 \mathrm{~cm}^{-3}$ at $150 \mathrm{~m}$ or just above cloud top. At the same time $N_{20-40}$ concentrations showed a similar increase. The increased UFP concentrations were vertically limited to near cloud top and decreased rapidly with increasing altitude. The same pattern is also observed for temperature, $\mathrm{H}_{2} \mathrm{O}$ and $\mathrm{CO}_{2}$ (Fig. 9g) suggesting the existence of a distinct air mass at the surface that gets diluted into the air mass above. Further east the flight was restricted to a slightly higher altitude above cloud top. At point $\mathrm{F}$, where we were close to the BL top, no peaks in particle concentrations were observed. At point $\mathrm{E}$, just before the ice edge, between the top of cloud and the top of the BL, UFP concentrations reached about $3400 \mathrm{~cm}^{-3}$.

Air mass histories at these locations determined from FLEXPART-WRF (Fig. 10) indicate the following:

1. To the west of Resolute Bay (point B), Lancaster Sound air masses had been mixed with air masses from the north. This is also confirmed by the local wind directions indicating winds coming from the northwest sector (Fig. 10a), and it is consistent with the associated change in cloud.

2. Near the top of the BL, air masses had descended recently $(<3 \mathrm{~h}$ ) into the BL (Fig. $10 \mathrm{c}$ point $\mathrm{C}$ and point $\mathrm{F}$ ).

3. In contrast, deeper within the BL at points $\mathrm{B}$ and $\mathrm{D}$, air masses had descended into the BL earlier $(\sim 20 \mathrm{~h})$ before arriving at the point of observation. In the case of point $\mathrm{D}$, where we observed the largest mode of UFP extending above $40 \mathrm{~nm}$, air masses had been travelling from the east exclusively over the open waters in Lancaster Sound during the last day before arriving at the point of observation.

Aerosol composition shows a clear difference between the aerosol in the FT and the BL. The aerosol sulfate rapidly decreases as we enter the BL around 16:00 UTC, while aerosol organic mass concentrations show an initial relative increase followed by an absolute increase towards the east (Fig. 9c). Within the BL, aerosol organics and sulfate mass loadings show a pattern similar to $N_{>40}$ and $N_{>} 80$. Both decrease each time we descended deeper into the BL. However, at the same time the organics-to-sulfate ratio indicates that the relative contribution of organics to aerosol mass increases at lower altitudes and especially above cloud (Fig. 9e). Well within the inversion layer and in the vicinity of cloud top the aerosol was dominated by organics. At the same time, also the ratio of MSA to sulfate was higher (Fig. 9e), suggesting a marine biogenic influence of the aerosol sulfur. The marine biogenic influence at the lower altitudes agrees well with the FLEXPART-WRF simulations showing that air masses at this altitude had spent almost an entire day exposed to the open waters in Lancaster Sound. Consistent with the higher organic content measured with the AMS, the single particle aerosol mass spectrometer ALABAMA (Brands et al., 2011; Willis et al., 2016) detected a higher fraction of trimethylamine (TMA)-containing particles for particles larger than $150 \mathrm{~nm}$ in diameter (F. Köllner, personal communication, July 2016). Gaseous TMA emissions from marine biogenic origin (Ge et al., 2011; Gibb et al., 1999) may have additionally favoured the subsequent growth of the freshly nucleated particles by condensation. Another possibility may be uptake of TMA in the cloud phase (Rehbein et al., 2011) if the particles have grown to sufficiently large sizes to be activated as $\mathrm{CCN}$. Interestingly, compared to other days these TMA-containing particles are smaller and to a lesser degree internally mixed with potassium and levoglucosan, which supports the hypothesis of ultrafine particles originating from nucleation in a biogenic marine environment and subsequent growth.

To explain these observations, we hypothesise that the smaller particle mode is formed by nucleation and growth occurring within the BL and especially in cloud vicinity. UFP concentrations near cloud top have been reported before (e.g. Radke and Hobbs, 1991, Wiedensohler et al., 1997, Clarke et al., 1999; Garrett et al., 2002; Hegg et al., 1990; Mauldin et al., 1997) and it is suggested that nucleation in near-cloud regions is favoured by the low surface areas, possibly due to cloud scavenged aerosol, moist air and a high actinic flux. Indeed, near cloud top, where we observed an increase of UFP extending up to almost $50 \mathrm{~nm}$, the conditions for nucleation and growth are ideal. We speculate that the availability of precursor gases is provided by the long residence time $(\sim 20 \mathrm{~h})$ of the air masses over open water (Fig. 10, point D). In other words, precipitating clouds scavenge aerosol parti- 


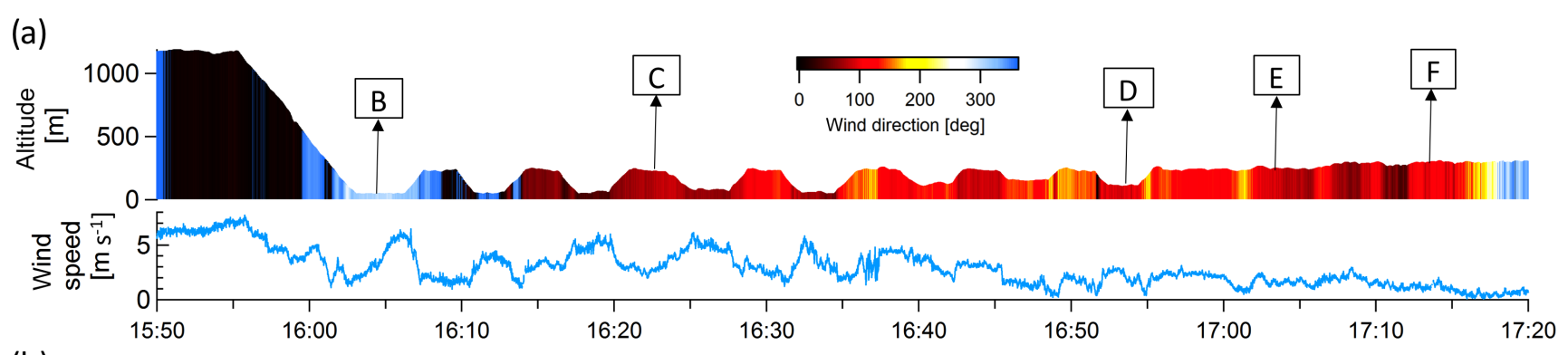

(b)
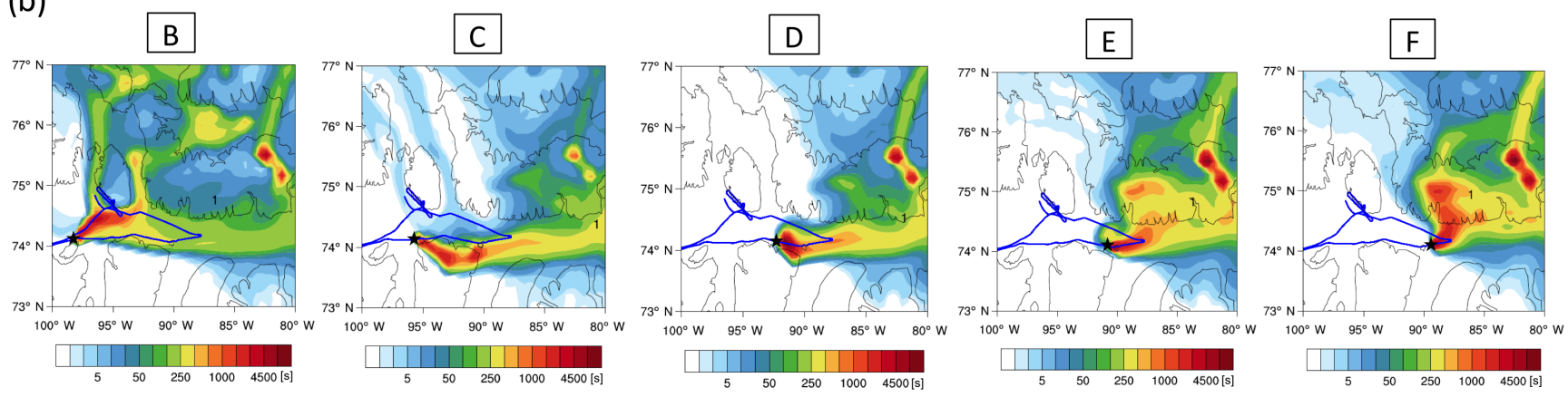

(c)
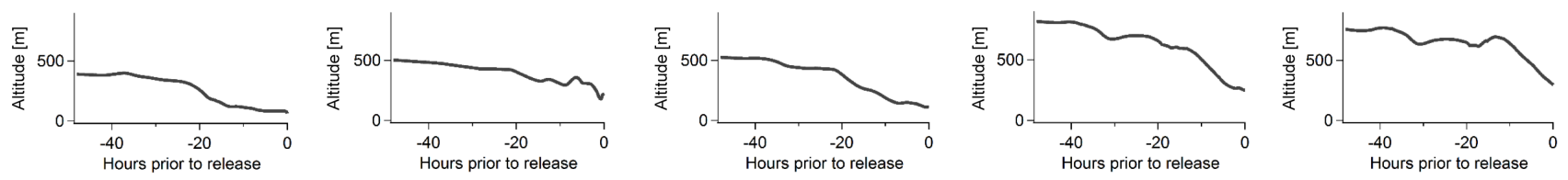

Figure 10. (a) Time series of aircraft altitude colour coded with the wind direction and time series of wind speed. (b) FLEXPART-WRF 7-day-backwards potential emissions sensitivities for points along the flight track ( $60 \mathrm{~s}$ release at indicated time and location) showing the air mass history at five representative locations within the BL. The plume centroid location for particles with an age of 1 day is indicated. (c) The bottom plots show the altitude of plume centroid $48 \mathrm{~h}$ backwards in time.

cles, reducing the surface area for condensation, but some fraction of nucleation precursor gases with lower Henry's law constants, can pass through (e.g. $\mathrm{SO}_{2}$ ) leaving the potential for $\mathrm{H}_{2} \mathrm{SO}_{4}$ in the higher $\mathrm{OH}$ in the cloud outflow (a discussion of the processes can be found in Seinfeld and Pandis, 2016). The very high organic loadings and MSA-to-sulfate ratio likely indicate that the formation and growth of these particles is driven by a combination of DMS and organic precursors (volatile organic compounds) that are emitted by the open ocean in Lancaster Sound (e.g. Chang et al., 2011; Sjostedt et al., 2012; Mungall et al., 2016).

The event at point $\mathrm{E}$ occurs where the aircraft was between cloud top and the top of the BL, where no increases in UFP were observed before or after. It may be that the aircraft descended slightly but sufficiently into the cloud-influenced area, which looks to be $25-40 \mathrm{~m}$ above cloud top (Fig. 9g), but also at that point we were in vicinity of Prince Leopold Island, which is a bird sanctuary and many bird colonies nest at the $260 \mathrm{~m}$ high cliff. FLEXPART-WRF and the in situ wind measurement show that air masses to a large extent were directly coming off the island (Fig. 10, point E) suggesting a connection between the appearance of UFP and possible emissions from the fauna of the island. The increase of particle phase ammonium (Fig. 9d) at the same time supports this connection and nucleation of particles from biogenic precursors emitted by bird colonies are documented (Weber et al., 1998; Wentworth et al., 2016, Croft et al., 2016b).

Alternatively, it should be considered that evaporating fog and cloud droplets may also act as a primary source of UFP (e.g. Heintzenberg et al., 2006; Karl et al., 2013; Leck and Bigg, 1999). Karl et al. (2013) suggested a combined pathway that involves the emission of UFP by fog and cloud droplets, together with secondary processes enabling growth of these particles. For our observations we have no reason to assume that nucleation does not occur since conditions are ideal but we cannot rule out that nanoparticles are emitted by the possibly evaporating cloud droplets onto which gases then condense.

In conclusion the aerosol mass within the near-surface layer is dominated by organics relative to sulfate, while at just a slightly higher altitude sulfate is clearly increased and increases further above the inversion layer. A high organic content coincides with increases in UFP particles, especially at times when also growth into the size range up to $50 \mathrm{~nm}$ is 

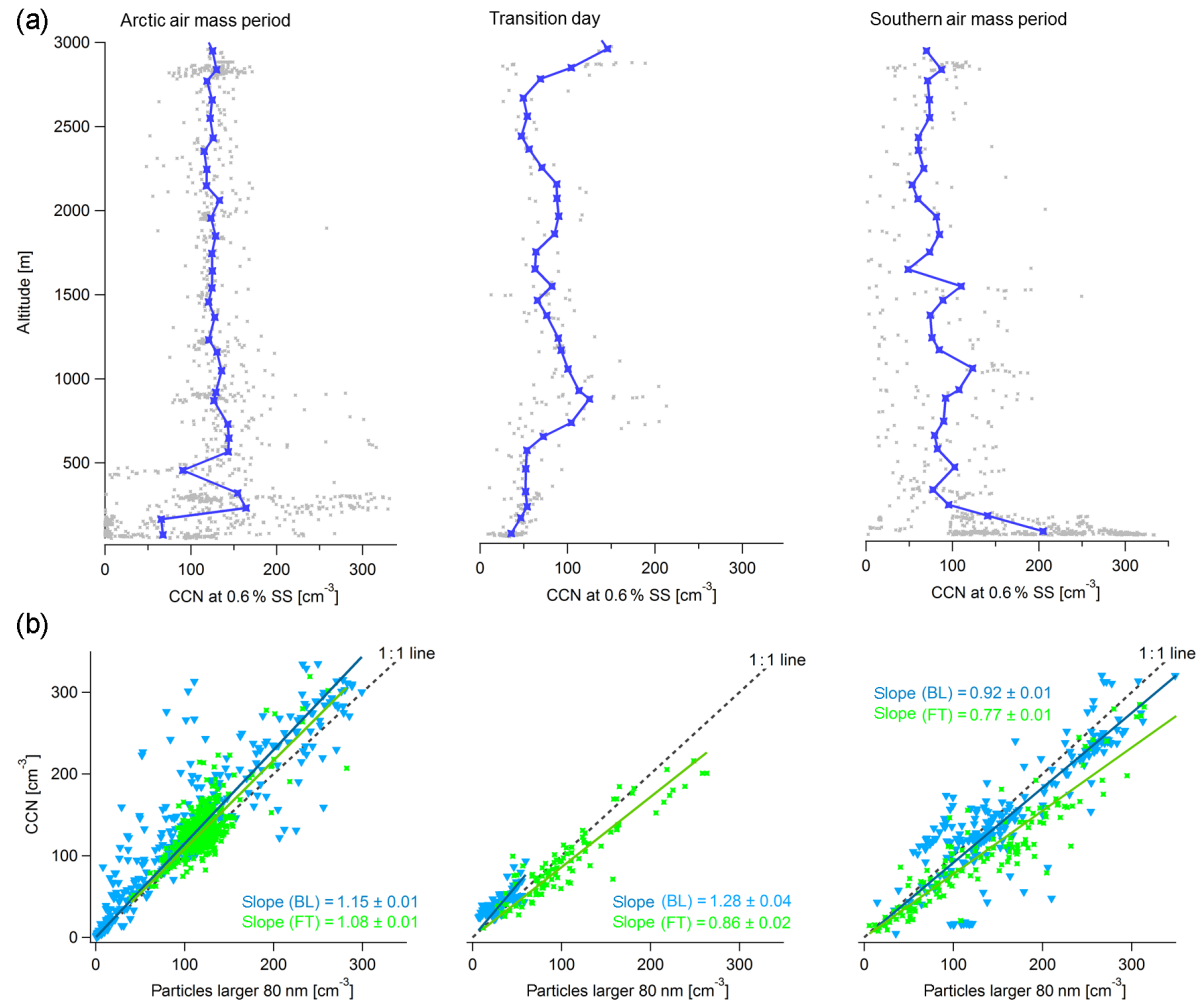

Figure 11. (a) Vertical profiles of average $\mathrm{CCN}$ concentrations (dark blue). All data points are plotted in light grey. (b) Correlation plots between CCN concentrations and particles larger than $80 \mathrm{~nm}$.

indicated. Similarly the MSA-to-sulfate ratio shows a peak at the lowest altitudes with maximum values in the vicinity of clouds that coincide with a long residence time $(\sim 20 \mathrm{~h})$ of the air masses within the BL and above open water. The data thereby suggest a marine biogenic influence of the aerosol within the lower layers of the atmosphere. We note that similarly high levels of aerosol organics and MSA were observed during the flight on 12 July associated with a NPF event and growth but in cloud-free conditions (Willis et al., 2016).

\subsection{CCN activity}

$\mathrm{CCN}$ concentrations were measured at a supersaturation of $0.6 \%$. The vertical profiles of CCN concentrations (Fig. 11a) show patterns similar to those of larger particles. In the very clean boundary layer of the Arctic air mass period and the transition day $\mathrm{CCN}$ concentrations are equally low $(\sim 70$ and $\sim 50 \mathrm{~cm}^{-3}$, respectively). In contrast, southern air mass period average $\mathrm{BL} \mathrm{CCN}$ concentrations are amongst the highest observed during this campaign $\left(>300 \mathrm{~cm}^{-3}\right)$. Within the free troposphere, $\mathrm{CCN}$ concentrations are surprisingly constant during the Arctic air mass period $\left(120 \pm 27 \mathrm{~cm}^{-3}\right)$ and more variable on the transition day $\left(92 \pm 46 \mathrm{~cm}^{-3}\right)$ and the southern air mass period $\left(103 \pm 67 \mathrm{~cm}^{-3}\right)$. The constant $\mathrm{CCN}$ concentrations during the Arctic air mass period correspond to the very uniform atmosphere dominated by aged aerosols we observed during this period and to the more layered atmosphere influenced by southern air masses possibly contaminated by biomass burning plumes during the later period. Correlations with $N_{>80}$ (Fig. 11b) confirm that larger particles are a good approximation for these $\mathrm{CCN}$ concentrations. On average $\mathrm{CCN}$ concentrations agree to within $\pm 20 \%$ of $N_{>80}$. However, it should be noted that slight differences between the three periods are indicated in the correlation curves; during the Arctic air mass period, the average activation diameters are smaller than $80 \mathrm{~nm}$, and during the southern air mass period they are larger than $80 \mathrm{~nm}$. Assuming uniform chemical composition throughout the particle size range, an activation diameter of $80 \mathrm{~nm}$ at $0.6 \%$ supersaturation indicates an aerosol much less hygroscopic than, for example, ammonium sulfate; pure ammonium sulfate particles would activate at $40 \mathrm{~m}$ at $0.6 \%$ supersaturation. For the one specific event during which growth occurred (Willis et al., 2016), it was demonstrated that high $\mathrm{CCN}$ concentrations coincide with elevated organic mass loading. The reduced hygroscopicity of organic material relative to soluble inorganic salts (Petters and Kreidenweis, 2007) can explain the larger effective activation diameter.

A central question is whether and to what degree the $\mathrm{CCN}$ are influenced by the UFP. Two factors help with addressing this question; (1) particles as small as $20 \mathrm{~nm}$ and in general much smaller than the average $80 \mathrm{~nm}$ size associated with 

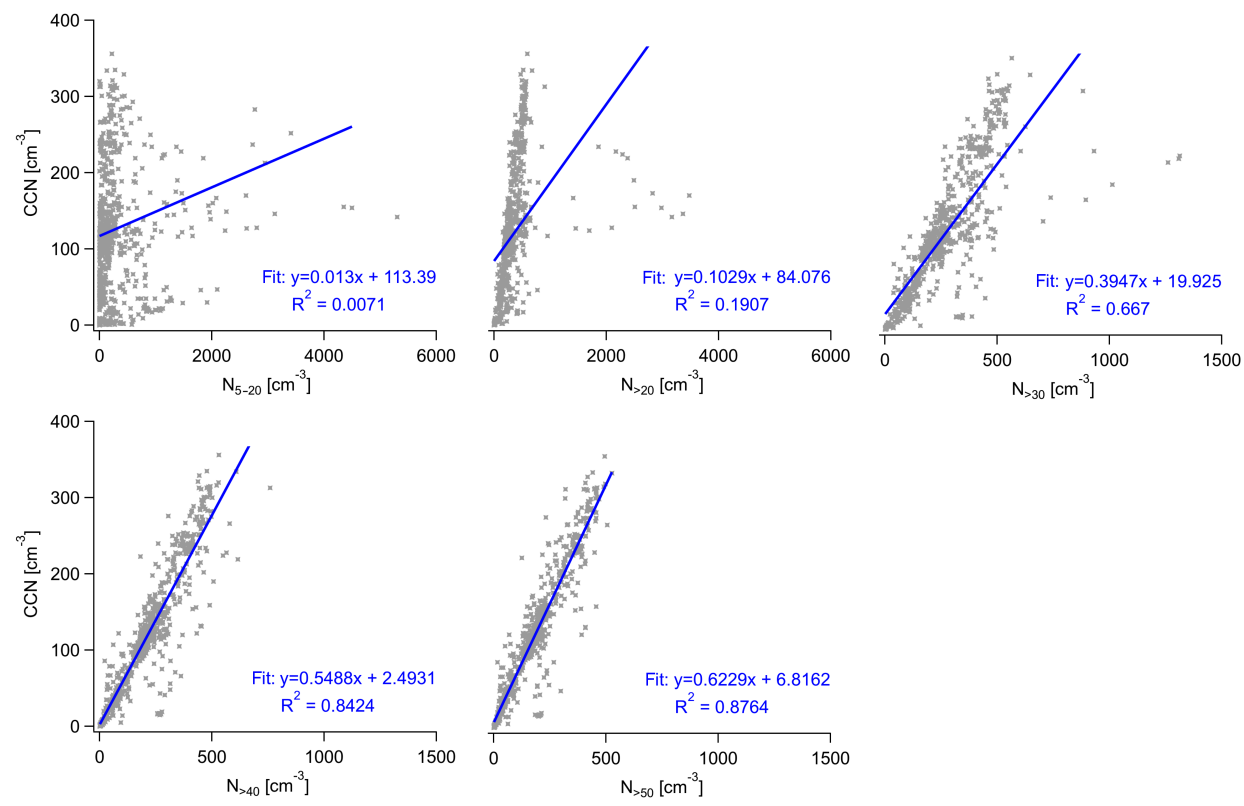

Figure 12. Correlations between $\mathrm{CCN}$ and particle concentrations for the full study period.

the $\mathrm{CCN}$ at $0.6 \%$ will nucleate cloud droplets in the clean environment of the summer Arctic (Leaitch et al., 2016), and (2) there is evidence here that increases in particles larger than $20 \mathrm{~nm}$ are associated with increases in the UFP, particularly for UFP influenced by clouds (e.g. Fig. 8). Figure 12 shows regressions of CCN with UFP, $N_{>20}, N_{>30}, N_{>40}$ and $N_{>50}$. The high variability in the UFP and the time needed for a UFP particle to grow to an average size of $80 \mathrm{~nm}$ under these low precursor levels does not permit a direct connection of the CCN and UFP, but in all other cases, the main clusters of the regressions show quite similar and strong connections with the CCN measurements. Associations of the UFP with the $N_{>20}$ in the BL mean that some of these UFP are able to contribute to cloud-nucleating particles.

\section{Discussion and conclusions}

This study presents airborne observations of ultrafine particles (UFP) during the Arctic summertime. In total, 11 flights were conducted in July 2014 in the area of Resolute Bay situated in the Canadian Archipelago. The location allowed access to open water, ice-covered regions and low clouds. Flights focused around the ice edge in Lancaster Sound including open waters to the east, the ice-covered region to the west and polynyas north of Resolute Bay. UFP were observed within all regions and above all terrains with the highest concentrations encountered in the boundary layer immediately above cloud and open water. It is shown that UFP occur most frequently ( $>65 \%$ of the time) and with the highest concentrations (up to $5300 \mathrm{~cm}^{-3}$ ) during an Arctic air mass period when the air is very clean and the boundary layer is thermally stable.

The frequent presence of UFP in the boundary layer over open water and low clouds and the enhanced number concentrations at the lowest altitudes sampled indicate a surface source, such as the ocean, for the UFP gaseous precursors. This is especially true during the Arctic air mass period when the sampling region was pristine and not influenced by pollution. FLEXPART-WRF simulations indicate that air masses had resided within the Arctic region at least 5-7 days prior to sampling. During this time UFP were restricted to the boundary layer and no UFP events were observed aloft, thereby excluding that these UFP form in the free troposphere and subside into the near-surface layer (e.g. Clarke et al., 1998; Quinn and Bates, 2011). At the same time we observed an extremely clean boundary layer (surface area of $N_{>40} \sim 5 \mu \mathrm{m}^{2} \mathrm{~m}^{-3}$ ). Low surface areas increase the probability of particle formation via nucleation by reducing the surfaces for precursor gases to condense on.

Chlorophyll $a$ concentrations (Fig. S5) indicate the relatively high level of biological activity in the ocean (such as phytoplankton blooms known to produce DMS) throughout Lancaster Sound, to the east in Baffin Bay and in the open waters of the polynyas during the time period of the study. Indeed, measurements in Lancaster Sound performed from the Amundsen ice breaker just a few days after the aircraft campaign show that gas-phase DMS mixing ratios were high in the Lancaster Sound region (Mungall et al., 2016), up to $1155 \mathrm{ppt}_{v}$. DMS was also measured from the Polar 6 aircraft with an offline technique. Maximum mixing ratios of $110 \mathrm{ppt}_{v}$ were detected in the surface layer (R. Ghahremaninezhad, personal communication, 2016), again confirming 
a marine influence in the boundary layer. The measured DMS concentrations are above the nucleation threshold obtained by modelling performed in the study of Chang et al. (2011), who concluded that DMS mixing ratios of $\geq 100 \mathrm{ppt}_{v}$ are sufficient to account for the formation of hundreds of UFP when background particle concentrations are low.

Relating observations of UFP to the surface below during the Arctic air mass period revealed that the highest UFP concentrations occurred above low-level cloud and open water with averages of 1040 and $560 \mathrm{~cm}^{-3}$, respectively. Above low-level cloud $N_{20-40}$ showed increased concentrations. This simultaneous increase in concentrations suggests that UFPs grow into the $40 \mathrm{~nm}$ size range, where they can nucleate cloud droplets.

Overall, the summertime Arctic is an active region in terms of new particle formation, occasionally accompanied by growth. The value of these altitude profiles across a wide spatial extent, performed for the first time in this campaign, is that they demonstrate that this activity is largely confined to the boundary layer, and that the dominant source of small particles to the boundary layer does not arise by mixing from aloft but most likely from marine sources. For future studies, the relative impact of such natural sources of UFP needs to be evaluated with respect to potential new sources, such as those that may arise with an increase in shipping.

Data availability. NETCARE (Network on Climate and Aerosols, 2015, http://www.netcare-project.ca), which organized the aircraft flights described in this paper, is moving towards a publicly available, online data archive. In the meantime, the data can be accessed by contacting the principal investigator of the network: Jon Abbatt at the University of Toronto (jabbatt@ chem.utoronto.ca)

\section{The Supplement related to this article is available online at doi:10.5194/acp-17-5515-2017-supplement.}

Competing interests. The authors declare that they have no conflict of interest.

Acknowledgements. The authors would like to thank a large number of people for their contributions to this work. We thank Kenn Borek Air, in particular the pilots Kevin Elke and John Bayes and the aircraft engineer Kevin Riehl. We are grateful to John Ford, David Heath and the University of Toronto machine shop for safely mounting our instruments on racks for aircraft deployment. We thank Jim Hodgson and Lake Central Air Services in Muskoka, Jim Watson (Scale Modelbuilders, Inc.), Julia Binder and Martin Gerhmann (Alfred Wegener Institute, Helmholtz Center for Polar Marine Research, AWI), and Mike Harwood and Andrew Elford (Environment and Climate Change Canada, ECCC) for their support of the integration of the instrumentation and aircraft. We gratefully acknowledge Carrie Taylor (ECCC), Bob Christensen (U of T), Lukas Kandora, Manuel Sellmann and Jens Herrmann (AWI), Desiree Toom, Sangeeta Sharma, Dan Veber, Andrew Platt, Anne Marie Macdonald, Ralf Staebler and Maurice Watt (ECCC) for their support of the study. We thank the Biogeochemistry department of MPIC for providing the $\mathrm{CO}$ instrument and Dieter Scharffe for his support during the preparation phase of the campaign. The authors J. L. Thomas and K. S. Law acknowledge funding support from the European Union under Grant Agreement no. 5265863 - ACCESS (Arctic Climate Change, Economy and Society) project (2012-2015) and TOTAL SA. Computer simulations were performed on the IPSL mesoscale computer centre (Mésocentre IPSL), which includes support for calculations and data storage facilities. We thank the Nunavut Research Institute and the Nunavut Impact Review Board for licensing the study. Logistical support in Resolute Bay was provided by the Polar Continental Shelf Project (PCSP) of Natural Resources Canada under PCSP Field Project no. 218614, and we are particularly grateful to Tim McCagherty and Jodi MacGregor of the PCSP. Funding for this work was provided by the Natural Sciences and Engineering Research Council of Canada through the NETCARE project of the Climate Change and Atmospheric Research Program, the Alfred Wegener Institute, Helmholtz Center for Polar and Marine Research and Environment and Climate Change Canada.

Edited by: L. M. Russell

Reviewed by: J. Heintzenberg and two anonymous referees

\section{References}

Agranovski, I. (Ed.): Aerosols: Science and Technology, 1st edition, WILEY-VCH Verlag GmbH \& Co, KGaA, Weinheim, 2010.

Aliabadi, A. A., Staebler, R. M., Liu, M., and Herber, A.: Characterization and Parametrization of Reynolds Stress and Turbulent Heat Flux in the Stably-Stratified Lower Arctic Troposphere Using Aircraft Measurements, Bound.-Lay. Meteorol., 161, 99126, doi:10.1007/s10546-016-0164-7, $2016 \mathrm{a}$.

Aliabadi, A. A., Staebler, R. M., de Grandpré, J., Zadra, A., and Vaillancourt, P. A.: Comparison of Estimated Atmospheric Boundary Layer Mixing Height in the Arctic and Southern Great Plains under Statically Stable Conditions: Experimental and Numerical Aspects, Atmos.-Ocean, 54, 60-74, doi:10.1080/07055900.2015.1119100, 2016b.

Asmi, E., Kondratyev, V., Brus, D., Laurila, T., Lihavainen, H., Backman, J., Vakkari, V., Aurela, M., Hatakka, J., Viisanen, Y., Uttal, T., Ivakhov, V., and Makshtas, A.: Aerosol size distribution seasonal characteristics measured in Tiksi, Russian Arctic, Atmos. Chem. Phys., 16, 1271-1287, doi:10.5194/acp-16-12712016, 2016.

Barrie, L. A.: Arctic air pollution: An overview of current knowledge, Atmos. Environ., 20, 643-663, doi:10.1016/00046981(86)90180-0, 1986.

Bigg, E. K. and Leck, C.: Properties of the aerosol over the central Arctic Ocean, J. Geophys. Res., 106, 32101, doi:10.1029/1999JD901136, 2001.

Boé, J., Hall, A., and Qu, X.: September sea-ice cover in the Arctic Ocean projected to vanish by 2100 , Nat. Geosci., 2, 341-343, doi:10.1038/ngeo467, 2009. 
Brands, M., Kamphus, M., Böttger, T., Schneider, J., Drewnick, F., Roth, A., Curtius, J., Voigt, C., Borbon, A., Beekmann, M., Bourdon, A., Perrin, T., and Borrmann, S.: Characterization of a Newly Developed Aircraft-Based Laser Ablation Aerosol Mass Spectrometer (ALABAMA) and First Field Deployment in Urban Pollution Plumes over Paris During MEGAPOLI 2009, Aerosol Sci. Technol., 45, 46-64, doi:10.1080/02786826.2010.517813, 2011.

Brioude, J., Arnold, D., Stohl, A., Cassiani, M., Morton, D., Seibert, P., Angevine, W., Evan, S., Dingwell, A., Fast, J. D., Easter, R. C., Pisso, I., Burkhart, J., and Wotawa, G.: The Lagrangian particle dispersion model FLEXPART-WRF version 3.1, Geosci. Model Dev., 6, 1889-1904, doi:10.5194/gmd-61889-2013, 2013.

Browse, J., Carslaw, K. S., Arnold, S. R., Pringle, K., and Boucher, O.: The scavenging processes controlling the seasonal cycle in Arctic sulphate and black carbon aerosol, Atmos. Chem. Phys., 12, 6775-6798, doi:10.5194/acp-12-6775-2012, 2012.

Browse, J., Carslaw, K. S., Mann, G. W., Birch, C. E., Arnold, S. R., and Leck, C.: The complex response of Arctic aerosol to sea-ice retreat, Atmos. Chem. Phys., 14, 7543-7557, doi:10.5194/acp14-7543-2014, 2014.

Carslaw, K. S., Lee, L. A., Reddington, C. L., Pringle, K. J., Rap, A., Forster, P. M., Mann, G. W., Spracklen, D. V., Woodhouse, M. T., Regayre, L. A., and Pierce, J. R.: Large contribution of natural aerosols to uncertainty in indirect forcing, Nature, 503, 67-71, doi:10.1038/nature12674, 2013.

Chang, R. Y. W., Sjostedt, S. J., Pierce, J. R., Papakyriakou, T. N., Scarratt, M. G., Michaud, S., Levasseur, M., Leaitch, W. R., and Abbatt, J. P. D.: Relating atmospheric and oceanic DMS levels to particle nucleation events in the Canadian Arctic, J. Geophys. Res.-Atmos., 116, 1-10, doi:10.1029/2011JD015926, 2011.

Charlson, R. J., Lovelock, J. E., Andreae, M. O., and Warren, S. G.: Oceanic phytoplankton, atmospheric sulphur, cloud albedo and climate, Nature, 326, 655-661, doi:10.1038/326655a0, 1987.

Clarke, A. D., Varner, J. L., Eisele, F., Mauldin, R. L., Tanner, D., and Litchy, M.: Particle production in the remote marine atmosphere?: Cloud outflow and subsidence during ACE 1, Earth Sci., 103, 16397-16409, doi:10.1029/97JD02987, 1998.

Clarke, A. D., Kapustin, V. N., Eisele, F. L., Weber, R. J., and McMurry, P. H.: Particle production near marine clouds: sulfuric acid and predictions from classical binary nucleation, Geophys. Res. Lett., 26, 2425-2428, doi:10.1029/1999GL900438, 1999.

Covert, D. S., Wiedensohler, A., Aalto, P., Heintzenberg, J., McMurry, P. H., and Leck, C.: Aerosol number size distributions from 3 to $500 \mathrm{~nm}$ diameter in the arctic marine boundary layer during summer and autumn, Tellus B, 48, 197-212, 1996.

Croft, B., Martin, R. V., Leaitch, W. R., Tunved, P., Breider, T. J., D'Andrea, S. D., and Pierce, J. R.: Processes controlling the annual cycle of Arctic aerosol number and size distributions, Atmos. Chem. Phys., 16, 3665-3682, doi:10.5194/acp-16-36652016, 2016a.

Croft, B., Wentworth, G. R., Martin, R. V., Leaitch, W. R., Murphy, J. G., Murphy, B. N., Kodros, J., Abbatt, J. P. D., and Pierce, J. R.: Contribution of Arctic seabird-colony ammonia to atmospheric particles and cloud-albedo radiative effect, Nat. Commun., 7, 13444, doi:10.1038/ncomms13444, 2016b.

DeCarlo, P. F., Kimmel, J. R., Trimborn, A., Northway, M. J., Jayne, J. T., Aiken, A. C., Gonin, M., Fuhrer, K., Horvath, T., Docherty,
K. S., Worsnop, D. R., and Jimenez, J. L.: Field-deployable, high-resolution, time-of-flight aerosol mass spectrometer, Anal. Chem., 78, 8281-8289, doi:10.1021/ac061249n, 2006.

Engvall, A.-C., Krecji, R., Sröm, J., Minikin, A., Treffeisen, R., Stohl, A., and Herber, A.: In-situ airborne observations of the microphysical properties of the Arctic tropospheric aerosol during late spring and summer, Tellus B, 60B, 392-404, doi:10.1111/j.1600-0889.2008.00348.x, 2008a.

Engvall, A.-C., Krejci, R., Ström, J., Treffeisen, R., Scheele, R., Hermansen, O., and Paatero, J.: Changes in aerosol properties during spring-summer period in the Arctic troposphere, Atmos. Chem. Phys., 8, 445-462, doi:10.5194/acp-8-445-2008, 2008b.

Fu, P. Q., Kawamura, K., Chen, J., and Barrie, L. A.: Isoprene, monoterpene, and sesquiterpene oxidation products in the high Arctic aerosols during late winter to early summer, Environ. Sci. Technol., 43, 4022-4028, 2009.

Garrett, T. J.: Effects of varying aerosol regimes on lowlevel Arctic stratus, Geophys. Res. Lett., 31, L17105, doi:10.1029/2004GL019928, 2004.

Garrett, T. J., Hobbs, P. V., and Radke, L. F.: High Aitken Nucleus Concentrations above Cloud Tops in the Arctic, J. Atmos. Sci., 59, 779-783, doi:10.1175/15200469(2001)059<0779:HANCAC>2.0.CO;2, 2002.

Garrett, T. J., Brattström, S., Sharma, S., Worthy, D. E. J., and Novelli, P.: The role of scavenging in the seasonal transport of black carbon and sulfate to the Arctic, Geophys. Res. Lett., 38, 1-6, doi:10.1029/2011GL048221, 2011.

Ge, X., Wexler, A. S., and Clegg, S. L.: Atmospheric amines - Part I. A review, Atmos. Environ., 45, 524-546, doi:10.1016/j.atmosenv.2010.10.012, 2011.

Gibb, S. W., Mantoura, R. F. C., and Liss, P. S.: Ocean-atmosphere exchange and atmospheric speciation of ammonia and methylamines in the region of the NW Arabian Sea, Global Biogeochem. Cy., 13, 161-178, doi:10.1029/98GB00743, 1999.

Hegg, D. A., Radke, L. F., and Hobbs, P. V.: Particle production associated with marine clouds, J. Geophys. Res.-Atmos., 95, 13917-13926, 1990.

Heintzenberg, B. J.: Particle size distribution and optical properties, Tellus, 32, 251-260, doi:10.1111/j.2153-3490.1980.tb00952.x, 1980.

Heintzenberg, B. and Leck, C.: Seasonal variation of the atmospheric aerosol near the top of the marine boundary layer over Spitsbergen related to the Arctic sulphur cycle, Tellus B, 46, 5267, doi:10.1034/j.1600-0889.1994.00005.x, 1994.

Heintzenberg, J. and Leck, C.: The summer aerosol in the central Arctic 1991-2008: did it change or not?, Atmos. Chem. Phys., 12, 3969-3983, doi:10.5194/acp-12-3969-2012, 2012.

Heintzenberg, B., Ström, J., Ogren, J. A., and Fimpel, H.-P.: Vertical profiles of aerosol properties in the summer troposphere of central Europe, scandinavia and the svalbard region, Atmos. Environ., 25, 621-627, doi:10.1016/0960-1686(91)90059-G, 1991.

Heintzenberg, J., Leck, C., Birmili, W., Wehner, B., Tjernström, M., and Wiedensohler, A.: Aerosol number-size distributions during clear and fog periods in the summer high Arctic: 1991, 1996 and 2001, Tellus B, 58B, 41-50, doi:10.1111/j.16000889.2005.00171.x, 2006.

Heintzenberg, J., Leck, C., and Tunved, P.: Potential source regions and processes of aerosol in the summer Arctic, Atmos. Chem. Phys., 15, 6487-6502, doi:10.5194/acp-15-6487-2015, 2015. 
Hoppel, W. A., Frick, G. M., Fitzgerald, J. W., and Larson, R. E.: Marine boundary layer measurements of new particle formation and the effects nonprecipitating clouds have on aerosol size distribution, J. Geophys. Res., 99, 14443, doi:10.1029/94JD00797, 1994.

Karl, M., Leck, C., Gross, A., and Pirjola, L.: A study of new particle formation in the marine boundary layer over the central Arctic Ocean using a flexible multicomponent aerosol dynamic model, Tellus B, 64, 1-24, doi:10.3402/tellusb.v64i0.17158, 2012.

Karl, M., Leck, C., Coz, E., and Heintzenberg, J.: Marine nanogels as a source of atmospheric nanoparticles in the high Arctic, Geophys. Res. Lett., 40, 3738-3743, doi:10.1002/grl.50661, 2013.

Kulmala, M., Dal Maso, M., Mäkelä, J. M., Pirjola, L., Väkevä, M., Aalto, P., Miikkulainen, P., Hämeri, K., and O'Dowd, C. D.: On the formation, growth and composition of nucleation mode particles, Tellus B, 53, 479-490, doi:10.1034/j.1600-0889.2001.d0133.x, 2001.

Kupiszewski, P., Leck, C., Tjernström, M., Sjogren, S., Sedlar, J., Graus, M., Müller, M., Brooks, B., Swietlicki, E., Norris, S., and Hansel, A.: Vertical profiling of aerosol particles and trace gases over the central Arctic Ocean during summer, Atmos. Chem. Phys., 13, 12405-12431, doi:10.5194/acp-13-12405-2013, 2013.

Law, K. S., Stohl, A., Quinn, P. K., Brock, C. A., Burkhart, J. F., Paris, J. D., Ancellet, G., Singh, H. B., Roiger, A., Schlager, H., Dibb, J., Jacob, D. J., Arnold, S. R., Pelon, J., and Thomas, J. L.: Arctic air pollution: New insights from POLARCAT-IPY, B. Am. Meteorol. Soc., 95, 1873-1895, doi:10.1175/BAMS-D-13$00017.1,2014$.

Leaitch, W. R., Hoff, R. M., Melnichuk, S., and Hogan, W.: Some chemical and physical properties of the Arctic winter aerosol in northeastern Canada, J. Climate Appl. Meteorol., 23, 916-928, doi:10.1175/1520-0450(1984)023<0916:SPACPO>2.0.CO;2, 1984.

Leaitch, W. R., Barrie, L. A., Bottenheim, J. W., Li, S.-M., Shepson, P., and Yokouchi, Y.: Airborne observations related ozone depletion at polar sunrise, J. Geophys. Res., 99, 25499-25517, doi:10.1029/94JD02750, 1994.

Leaitch, W. R., Sharma, S., Huang, L., Toom-Sauntry, D., Chivulescu, A., Macdonald, A. M., von Salzen, K., Pierce, J. R., Bertram, A. K., Schroder, J. C., Shantz, N. C., Chang, R. Y. W., and Norman, A.-L.: Dimethyl sulfide control of the clean summertime Arctic aerosol and cloud, Elem. Sci. Anth., 1, 1-17, doi:10.12952/journal.elementa.000017, 2013.

Leaitch, W. R., Korolev, A., Aliabadi, A. A., Burkart, J., Willis, M. D., Abbatt, J. P. D., Bozem, H., Hoor, P., Köllner, F., Schneider, J., Herber, A., Konrad, C., and Brauner, R.: Effects of 20$100 \mathrm{~nm}$ particles on liquid clouds in the clean summertime Arctic, Atmos. Chem. Phys., 16, 11107-11124, doi:10.5194/acp-1611107-2016, 2016.

Leck, C. and Bigg, E. K.: Aerosol production over remote marine areas-A new route, Geophys. Res. Lett., 26, 3577, doi:10.1029/1999GL010807, 1999.

Leck, C. and Bigg, E. K.: Source and evolution of the marine aerosol - A new perspective, Geophys. Res. Lett., 32, 1-4, doi:10.1029/2005GL023651, 2005.

Leck, C. and Bigg, E. K.: New Particle Formation of Marine Biological Origin, Aerosol Sci. Technol., 44, 570-577, doi:10.1080/02786826.2010.481222, 2010.
Lohmann, U. and Feichter, J.: Global indirect aerosol effects: a review, Atmos. Chem. Phys., 5, 715-737, doi:10.5194/acp-5-7152005, 2005.

Mauldin, R. L., Madronich, S., Flocke, S. J., Eisele, F. L., Frost, G. J., and Prevot, A. S. H. : New insights on OH: Measurements around and in clouds, Geophys. Res. Lett., 24, 3033-3036, doi:10.1029/97GL02983, 1997.

Mauritsen, T., Sedlar, J., Tjernström, M., Leck, C., Martin, M., Shupe, M., Sjogren, S., Sierau, B., Persson, P. O. G., Brooks, I. M., and Swietlicki, E.: An Arctic CCN-limited cloud-aerosol regime, Atmos. Chem. Phys., 11, 165-173, doi:10.5194/acp-11165-2011, 2011.

Mungall, E. L., Croft, B., Lizotte, M., Thomas, J. L., Murphy, J. G., Levasseur, M., Martin, R. V., Wentzell, J. J. B., Liggio, J., and Abbatt, J. P. D.: Dimethyl sulfide in the summertime Arctic atmosphere: measurements and source sensitivity simulations, Atmos. Chem. Phys., 16, 6665-6680, doi:10.5194/acp-16-66652016, 2016.

Nguyen, Q. T., Glasius, M., Sørensen, L. L., Jensen, B., Skov, H., Birmili, W., Wiedensohler, A., Kristensson, A., Nøjgaard, J. K., and Massling, A.: Seasonal variation of atmospheric particle number concentrations, new particle formation and atmospheric oxidation capacity at the high Arctic site Villum Research Station, Station Nord, Atmos. Chem. Phys., 16, 11319-11336, doi:10.5194/acp-16-11319-2016, 2016.

Petters, M. D. and Kreidenweis, S. M.: A single parameter representation of hygroscopic growth and cloud condensation nucleus activity, Atmos. Chem. Phys., 7, 1961-1971, doi:10.5194/acp-71961-2007, 2007.

Pierce, J. R., Leaitch, W. R., Liggio, J., Westervelt, D. M., Wainwright, C. D., Abbatt, J. P. D., Ahlm, L., Al-Basheer, W., Cziczo, D. J., Hayden, K. L., Lee, A. K. Y., Li, S.-M., Russell, L. M., Sjostedt, S. J., Strawbridge, K. B., Travis, M., Vlasenko, A., Wentzell, J. J. B., Wiebe, H. A., Wong, J. P. S., and Macdonald, A. M.: Nucleation and condensational growth to $\mathrm{CCN}$ sizes during a sustained pristine biogenic SOA event in a forested mountain valley, Atmos. Chem. Phys., 12, 3147-3163, doi:10.5194/acp-12-3147-2012, 2012.

Pirjola, L., O'Dowd, C. D., Brooks, I. M., and Kulmala, M.: Can new particle formation occur in the clean marine boundary layer?, J. Geophys. Res.-Atmos., 105, 26531-26546, doi:10.1029/2000JD900310, 2000.

Quinn, P. K. and Bates, T. S.: The case against climate regulation via oceanic phytoplankton sulphur emissions, Nature, 480, 5156, doi:10.1038/nature10580, 2011.

Quinn, P. K., Shaw, G., Andrews, E., Dutton, E. G., RuohoAirola, T., and Gong, S. L.: Arctic haze: Current trends and knowledge gaps, Tellus B, 59, 99-114, doi:10.1111/j.16000889.2006.00238.x, 2007.

Radke, F. L. and Hobbs, P. V.: Humidity and particle fields around some small cumulus clouds, J. Atmos. Sci., 48, 1190-1193, doi:10.1175/1520-0469(1991)048<1190:HAPFAS>2.0.CO;2, 1991.

Rahn, K. A., Borys, R. D., and Shaw, G. E.: The Asian source of Arctic haze bands, Nature, 268, 713-715, doi:10.1038/268713a0, 1977.

Rehbein, P. J. G., Jeong, C. H., McGuire, M. L., Yao, X., Corbin, J. C., and Evans, G. J.: Cloud and fog processing enhanced gas-to- 
particle partitioning of trimethylamine, Environ. Sci. Technol., 45, 4346-4352, doi:10.1021/es1042113, 2011.

Seinfeld, J. H. and Pandis, S. N.: Atmospheric Chemistry and Physics: From Air Pollution to Climate Change, 3rd Edition, John Wiley \& Sons, Inc., 2016.

Shaw, G. E.: The Arctic Haze Phenomenon, B. Am. Meteorol. Soc., 76, 2403-2413, doi:10.1175/15200477(1995)076<2403:TAHP>2.0.CO;2, 1995.

Skamarock, W. C., Klemp, J. B., Dudhia, J., Gill, D. O., Barker, D. M., Wang, W., and Powers, J. G.: A Description of the Advanced Research WRF Version 2, available at: http://oai.dtic.mil/oai/oai?verb=getRecord\&metadataPrefix= html\&identifier=ADA487419 (last access: 22 March 2016), 2005.

Sjostedt, S. J., Leaitch, W. R., Levasseur, M., Scarratt, M., Michaud, S., Motard-Côté, J., Burkhart, J. H., and Abbatt J.: Evidence for the uptake of atmospheric acetone and methanol by the Arctic Ocean during late summer DMS-Emission plumes, J. Geophys. Res., 117, D12303, doi:10.1029/2011JD017086, 2012.

Stohl, A., Forster, C., Frank, A., Seibert, P., and Wotawa, G.: Technical note: The Lagrangian particle dispersion model FLEXPART version 6.2, Atmos. Chem. Phys., 5, 2461-2474, doi:10.5194/acp-5-2461-2005, 2005.

Ström, J., Umegård, J., Tørseth, K., Tunved, P., Hansson, H. C., Holmén, K., Wismann, V., Herber, A., and König-Langlo, G.: One year of particle size distribution and aerosol chemical composition measurements at the Zeppelin Station, Svalbard, March 2000-March 2001, Phys. Chem. Earth, 28, 1181-1190, doi:10.1016/j.pce.2003.08.058, 2003.

Ström, J., Engvall, A. C., Delbart, F., Krejci, R., and Treffeisen, R.: On small particles in the Arctic summer boundary layer: Observations at two different heights near Ny-Ålesund, Svalbard, Tellus B, 61, 473-482, doi:10.1111/j.1600-0889.2008.00412.x, 2009.

Tjernström, M., Birch, C. E., Brooks, I. M., Shupe, M. D., Persson, P. O. G., Sedlar, J., Mauritsen, T., Leck, C., Paatero, J., Szczodrak, M., and Wheeler, C. R.: Meteorological conditions in the central Arctic summer during the Arctic Summer Cloud Ocean Study (ASCOS), Atmos. Chem. Phys., 12, 6863-6889, doi:10.5194/acp-12-6863-2012, 2012.

Tjernström, M., Leck, C., Birch, C. E., Bottenheim, J. W., Brooks, B. J., Brooks, I. M., Bäcklin, L., Chang, R. Y.-W., de Leeuw, G., Di Liberto, L., de la Rosa, S., Granath, E., Graus, M., Hansel, A., Heintzenberg, J., Held, A., Hind, A., Johnston, P., Knulst, J., Martin, M., Matrai, P. A., Mauritsen, T., Müller, M., Norris, S. J., Orellana, M. V., Orsini, D. A., Paatero, J., Persson, P. O. G., Gao, Q., Rauschenberg, C., Ristovski, Z., Sedlar, J., Shupe, M. D., Sierau, B., Sirevaag, A., Sjogren, S., Stetzer, O., Swietlicki, E., Szczodrak, M., Vaattovaara, P., Wahlberg, N., Westberg, M., and Wheeler, C. R.: The Arctic Summer Cloud Ocean Study (ASCOS): overview and experimental design, Atmos. Chem. Phys., 14, 2823-2869, doi:10.5194/acp-14-2823-2014, 2014.
Tunved, P., Ström, J., and Krejci, R.: Arctic aerosol life cycle: linking aerosol size distributions observed between 2000 and 2010 with air mass transport and precipitation at Zeppelin station, Ny-Ålesund, Svalbard, Atmos. Chem. Phys., 13, 3643-3660, doi:10.5194/acp-13-3643-2013, 2013.

Twomey, S.: Pollution and the Planetary Albedo, Atmos. Environ., 41, 1251-1256, doi:10.1016/j.atmosenv.2007.10.062, 1974.

Wang, M. and Overland, J. E.: A sea ice free summer Arctic within 30 years: An update from CMIP5 models, Geophys. Res. Lett., 39, 2-6, doi:10.1029/2012GL052868, 2012.

Weber, R. J., McMurry, P. H., Mauldin, L., Tanner, D. J., Eisele, F. L., Brechtel, F. J., Kreidenweis, S. M., Kok, G. L., Schillawski, R. D., and Baumgardner, D.: A study of new particle formation and growth involving biogenic and trace gas species measured during ACE 1, J. Geophys. Res., 103, 16385-16396, doi:10.1029/97JD02465, 1998.

Wentworth, G. R., Murphy, J. G., Croft, B., Martin, R. V., Pierce, J. R., Côté, J.-S., Courchesne, I., Tremblay, J.-É., Gagnon, J., Thomas, J. L., Sharma, S., Toom-Sauntry, D., Chivulescu, A., Levasseur, M., and Abbatt, J. P. D.: Ammonia in the summertime Arctic marine boundary layer: sources, sinks, and implications, Atmos. Chem. Phys., 16, 1937-1953, doi:10.5194/acp-16-19372016, 2016.

Wiedensohler, A., Covert, D. S., Swietlicki, E., Aalto, P., Heintzenberg, J., and Leck, C.: Occurrence of an ultrafine particle mode less than $20 \mathrm{~nm}$ in diameter in the marine boundary layer during Arctic summer and autumn, Tellus B, 48, 213-222, doi:10.1034/j.1600-0889.1996.t01-1-00006.x, 1996.

Wiedensohler, A., Hansson, H. C., Orsini, D., Wendisch, M., Wagner, F., Bower, K. N., Chourlarton, T. W., Wells, M., Parkini, M., Acker, K., Wieprecht, W., Facchini, M. C., Lind, J. A., and Kulmala, M.: Night-time formation and occurrence of new particles associated with orographic clouds, Atmos. Environ., 31, 25452559, doi:10.1016/S1352-2310(96)00299-3, 1997.

Willis, M. D., Burkart, J., Thomas, J. L., Köllner, F., Schneider, J., Bozem, H., Hoor, P. M., Aliabadi, A. A., Schulz, H., Herber, A. B., Leaitch, W. R., and Abbatt, J. P. D.: Growth of nucleation mode particles in the summertime Arctic: a case study, Atmos. Chem. Phys., 16, 7663-7679, doi:10.5194/acp-16-76632016, 2016.

Zhang, J., Spitz, Y. H., Steele, M., Ashjian, C., Campbell, R., Berline, L., and Matrai, P.: Modeling the impact of declining sea ice on the Arctic marine planktonic ecosystem, J. Geophys. Res. Ocean., 115, 1-24, doi:10.1029/2009JC005387, 2010. 